This item was submitted to Loughborough's Research Repository by the author.

Items in Figshare are protected by copyright, with all rights reserved, unless otherwise indicated.

\title{
Growth and returns to new products and pack varieties: the case of UK pharmaceuticals
}

PLEASE CITE THE PUBLISHED VERSION

http://competitionpolicy.ac.uk/publications/working-papers

PUBLISHER

UEA Centre for Competition Policy

VERSION

VoR (Version of Record)

\section{PUBLISHER STATEMENT}

This work is made available according to the conditions of the Creative Commons Attribution-NonCommercialNoDerivatives 4.0 International (CC BY-NC-ND 4.0) licence. Full details of this licence are available at: https://creativecommons.org/licenses/by-nc-nd/4.0/

\section{LICENCE}

CC BY-NC-ND 4.0

\section{REPOSITORY RECORD}

Bennato, Anna R., Farasat A.S. Bokhari, and Franco Mariuzzo. 2019. "Growth and Returns to New Products and Pack Varieties: The Case of UK Pharmaceuticals". figshare. https://hdl.handle.net/2134/23647. 


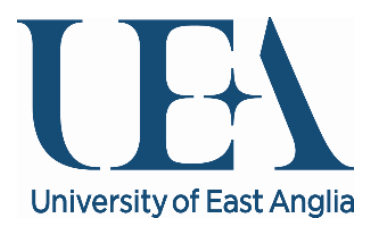

\title{
c'p
}

\section{Growth and returns to new products and pack varieties: The case of UK pharmaceuticals}

\author{
Anna Rita Bennato \\ Centre for Competition Policy, University of East Anglia \\ Department of Accounting, Finance and Economics, Oxford Brookes \\ University \\ Farasat A.S. Bokhari \\ Centre for Competition Policy and School of Economics, \\ University of East Anglia \\ Franco Mariuzzo \\ Centre for Competition Policy and School of Economics, \\ University of East Anglia \\ CCP Working Paper 16-1
}

\begin{abstract}
We use quarterly sales data from the UK pharmaceuticals market between 2003 and 2013 and estimate the impact of new introductions, i.e., new products and pack varieties within an anatomical therapy class on business unit growth. Using a dynamic lag adjustment growth model that accounts for endogeneity of new introductions, we find that a new product contributes to 18 per cent growth of the business unit while a new pack variety leads to 7 per cent growth for the business unit in the long run. Further, we find that there is significant variation in growth by size of firm and that the marginal effect of additional products on growth is larger for smaller business units. However, the marginal effect of pack varieties does not differ by firm size.
\end{abstract}

Contact Details:

Farasat Bokhari_f.bokhari@uea.ac.uk

The authors wish to acknowledge the contribution of the ESRC who supported their research through Centre for Competition Policy funding (ref: RES-578-28-0002). 


\title{
Growth and returns to new products and pack varieties: The case of UK pharmaceuticals ${ }^{\dagger}$
}

\author{
Anna Rita Bennato ${ }^{a, c}$, Farasat A.S. Bokhari ${ }^{a, b}$, Franco Mariuzzo a,b \\ ${ }^{a}$ Centre for Competition Policy, University of East Anglia, Norwich NR4 7TJ, UK \\ ${ }^{\mathrm{b}}$ School of Economics, University of East Anglia, Norwich NR4 7TJ, UK \\ ${ }^{\mathrm{c}}$ Department of Accounting, Finance and Economics, Oxford Brookes University, Oxford OX33 1HX, UK
}

January 7, 2016

\begin{abstract}
We use quarterly sales data from the UK pharmaceuticals market between 2003 and 2013 and estimate the impact of new introductions, i.e., new products and pack varieties within an anatomical therapy class on business unit growth. Using a dynamic lag adjustment growth model that accounts for endogeneity of new introductions, we find that a new product contributes to 18 per cent growth of the business unit while a new pack variety leads to 7 per cent growth for the business unit in the long run. Further, we find that there is significant variation in growth by size of firm and that the marginal effect of additional products on growth is larger for smaller business units. However, the marginal effect of pack varieties does not differ by firm size.
\end{abstract}

Key words: Pharmaceuticals, growth, product differentiation, non-linear pricing.

JEL Classification: F12, L25, L20.

\section{INTRODUCTION}

Product differentiation and non-linear pricing can be important strategies for firm growth. Competing firms can offer horizontally differentiated products to soften competition when consumers have distinct preferences over attributes and increase their revenues and profits. For example, rather than sell a medium sized shirt at an average price for all consumers, firms can offer large and small shirts at higher prices as long as there is enough of a mass of consumers at each product location to justify the additional cost of producing two horizontally differentiated products rather than one. Barring threat of entry, a monopolist on the other hand may continue to produce a single sized shirt, but can use non-linear pricing (or price discrimination more generally), to capture a larger

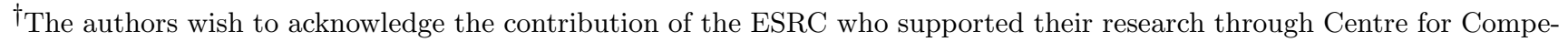
tition Policy funding (ref: RES-578-28-0002). The usual caveat applies.

${ }^{*}$ Corresponding Author: Farasat Bokhari (f.bokhari@uea.ac.uk)
} 
share of the consumer's surplus when consumers differ in their willingness to pay for a given product. ${ }^{1}$ In pharmaceuticals, product differentiation and price discrimination are sometimes achieved by introducing new varieties of existing products. A new variety may introduce a different molecule or a new delivery mechanism for an existing drug that allows a firm to differentiate their drug from that of a competitor, such as an extended release drug, or it may be a variation in pack size or strength that allows the firm to price discriminate by charging different price per unit of quantity. The use of these two different approaches is not peculiar to modern pharmaceutical companies, as both strategies have been widely recognized in the industry in the past (Comanor, 1964, 1986, Lu and Comanor, 1998).

Building on the insights from Hall (1987), Geroski and Machin (1992), Geroski and Toker (1996), Freel (2000), Del Monte and Papagni (2003) and Demirel and Mazzucato (2012), that innovative and/or more R\&D active firms outperform non-innovating firms, in this paper we quantify the returns from introducing additional drugs or products within the same therapeutic class, and from introducing additional packs for a given drug on a business unit's growth. ${ }^{2}$ We think of introduction of new products within the same therapeutic class as a product differentiation strategy that requires innovation and $R \& D$ by the firm, and that of introducing additional packs that vary by strength or size as a non-linear pricing strategy by the firm. We use quarterly sales data from the UK pharmaceutical prescription market during the 2003-2014 period to measure firms' growth by therapeutic class, i.e., by the business unit, and identify the impact of additional product forms and of new pack varieties on growth. By focusing on business unit as opposed to firm level analysis, we are better able to measure the impact of follow-on products and pack variation on revenue growth by the relevant sub-market. We treat the introduction of new products and packs as potentially endogenous and instrument for these variables in a dynamic growth model.

Similar to some of other studies (e.g., Dunne and Hughes, 1994, Bottazzi and Secchi, 2003) we find that smaller firms grow faster than larger ones. Our main result is that the introduction of new formulations, as well as of new packs, has a significant impact on growth in the short run, but only new forms have a long term effect on growth. Further, we find that new product introductions have a stronger effect on growth for smaller business units than larger ones. However, the marginal effect of pack varieties is much smaller in magnitude and does not statistically differ by the size of the business unit. In this respect, that the marginal effect of new products is larger for smaller firms is perhaps consistent with Demirel and Mazzucato (2012), who report positive impact of R\&D on growth for small firms, albeit as long as they are patenting consistently.

\footnotetext{
${ }^{1}$ There is a large literature on product differentiation and price discrimination and its review is not possible here. Interested readers are directed to Bonanno (1987), Armstrong and Vickers (2001), Varian (1995, 1989) and Stole (2007).

${ }^{2}$ On the other hand, lack of such positive relationship is reported in Geroski et al. (1997) and Bottazzi et al. (2001).
} 
Product proliferation has long been recognized as a strategy to consolidate incumbent's market power by creating entry barriers for potential entrants (Bonanno, 1987). In a work based on the US pharmaceutical data, Ellison and Ellison (2011) examine adjustments to presentation-level productmix by pharmaceutical firms just before the patent expires, and find (weak) evidence that product proliferation delays generic entry. On the other hand, Appelt (2015) uses German pharmaceutical data and finds that while a manufacturer with a patented drug may launch an additional equivalent product as an authorized generic prior to patent expiration, this in itself does not lower the likelihood of an independent generic entry post patent expiration. Similarly, Kyle (2011) shows that product differentiation has also been a strategic response to changes in intellectual property rights and trade barriers that legalized parallel imports within the European Union (EU). ${ }^{3}$

Small variations of existing products by molecule or form within a therapeutic class are called follow-on or 'me-too' drugs in the literature, and their introduction has been criticized as a work around to intellectual property rights and its limits (Lichtenberg and Philipson, 2002, Goozner, 2004, Hollis, 2004, 2005). A pioneer may introduce a follow-on drug as an attempt to extend the monopoly period of its original drug, or alternatively a competitor may introduce a me-too as a work-around the patented drug of a pioneer. Nonetheless, to the extent that these non-pioneer second generation drugs within a therapeutic class are not necessarily superior to the original drug for all patients (i.e., are not always vertically differentiated), they may be better for some patients and provide opportunity for increasing firm profit via horizonal differentiation. For instance, metoo drugs may provide substantial welfare gains by lowering the side effects of the pioneer drugs, changing the delivery mechanism, or targeting a new sub-population and effectively increasing the market size (Frijlink, 2003, DiMasi and Paquette, 2004, DiMasi and Faden, 2011, Arcidiacono et al., 2013, Bokhari and Fournier, 2013).

However, product differentiation in pharmaceuticals is risky as it requires substantial R\&D and years of clinical trials, and thus a monopolist may not necessarily undertake developing a new formulation absent any competition, or threat of competition (say due to patent expiration) from other manufacturers. An example of such a case is the introduction of Adderall XR by Shire which helped preserve its market shares. In 2000, Shire had 31.1\% share of the US ADHD drug market (psychostimulants) via its popular drug Adderall. At the time there were seven other brand name firms and more than a dozen generic manufactures also producing other ADHD drugs using different molecules, but due to a patent, which was valid for another two years, Shire was the only one using the mixed amphetamine salt as the main active ingredient. Perhaps due to the threat of the imminent entry by generics in two years (i.e., in 2002), Shire was able to engineer the timing of

\footnotetext{
${ }^{3}$ For instance, since manufactures price discriminate across countries, but are subject to threat of arbitrage by wholesale parallel importers, product and pack variations increase transaction costs for the wholesalers as separate import licenses are needed for each form and dosage variety.
} 
introducing an extended release version, Adderall XR in 2001, also under a patent for its delivery mechanism. One year post-entry by the generic manufactures for the non-XR version of mixed amphetamine salt, share of the generics was 7.6\%, that of Adderall was $2.9 \%$, but that of Adderall XR was 23.8\% (Bokhari and Fournier, 2013). As this example shows, Shire's share of the ADHD drug market could have been much smaller had it not introduced this blockbuster me-too as an extended release version of an older drug. Thus, while the strategy of new product introduction as a me-too to maintain or increase market shares is risky due to the stochastic nature of R\&D and market authorization process, the rewards to the firm may be high and may contribute to firm growth.

An alternative strategy to product differentiation, and perhaps less risky in terms of the required $\mathrm{R} \& \mathrm{D}$ and control over timing of introduction, is for the firm to engage in price discrimination when possible. The empirical literature has focused on both the pricing strategies of originators postpatent expiration (Frank and Salkever, 1992, Scherer, 1993, Regan, 2008) as well as on prices of the follow-on and generics (Lu and Comanor, 1998, Ekelund and Persson, 2003, Danzon and Furukawa, 2011, Mueller and Frenzel, 2015). There is a large literature on price discrimination (third degree) and welfare effects (Scherer, 2000, Danzon, 1997, Malueg and Schwartz, 1994) and when in the presence of heterogeneous consumers firms can profitably divide the market in different brand loyal and not-brand loyal groups via advertising to achieve second degree price discrimination (de Frutos et al., 2013).

Apart from the classical third degree price discrimination, which applies to consumers organized in groups, i.e. inter-personal pricing (see Varian, 1995), pharmaceutical companies can employ product line pricing or second-degree price discrimination, i.e. intra-personal price discrimination, which aims at capturing consumer types who would not be attracted otherwise (Armstrong and Vickers, 2001). In many industries, this latter method is favored when consumers value firms' product-line breadth, which permits them to avoid extra costs caused by incompatible products or unknown brands (Klemperer, 1995). This can explain why in the pharmaceutical sector firms tend to offer alternative varieties of the same drug under different format and quantity. It is achieved via the introduction of additional packs that differ exclusively in quantity per pack and the price of the pack. Thus, it is the result of a firm offering the same drug - molecule and form - in a different size or strength, e.g. 20mg 28-pill pack versus 20mg 14-pill pack, where the price of the latter is not half of the first pack, and similarly other combinations of strength and volume in different price per unit of quantity.

The introduction of different packages for an already existing product is considered an important strategic tool since it intensifies the firm's market power and also increases the revenues of the initial good introduced as first in the market (Klemperer and Padilla, 1997). There are clear examples of 
this non-linear pricing in the UK pharmaceutical data. For instance, Abbot's Prothiaden, a selective serotonin reuptake inhibitor (SSRI) with dosulepin hydrochloride as the main active ingredient and used for treating depression, was sold in the UK in 2003 as a $75 \mathrm{mg} 28$-tabs pack for £4.20 per pack or as $75 \mathrm{mg} 500$-tabs pack for $£ 85.81$, which work out to £2.00 per gram and £2.88 per gram respectively. Similarly, GlaxoSmithKline's Sextrostat (also an SSRI with active ingredient paroxetine) was available in two formulations: liquid oral suspension and tablets, where the latter form was available as $20 \mathrm{mg} 30$-tabs for $£ 17.76$ per pack and $30 \mathrm{mg} 30$-tabs for $£ 31.16$ per pack, i.e., at $£ 29.60$ and $£ 34.62$ per gram respectively. While it is certainly true that pack variation, especially one originating due to the difference in strength of $20 \mathrm{mg}$ versus $30 \mathrm{mg}$, as in the Sextrostat example above, is also a form of horizontal product differentiation, our data suggests that pack variety in this industry, much like other industries, is perhaps best understood as a mechanism for non-linear pricing rather than pure product differentiation.

In the next section we provide some background on the British pharmaceutical industry and discuss our sales data within this context. Section 3 describes our empirical strategy as well as discusses our instruments for the endogenous variables and section 4 presents and discusses the results. The last section concludes.

\section{DAtA AND BACKGROUND}

The pharmaceutical sector in the UK is a crucial element of the manufacturing industry with a long tradition in research and development (R\&D) of new drugs and treatments. In 2011, pharmaceutical R\&D expenditures were $£ 4.9$ billion, and accounted for $28 \%$ of all R\&D expenditures in the UK. According to the Association of the British Pharmaceutical Industry (ABPI), more than $36 \%$ of sales are invested in R\&D with the aim to introduce new drugs to the market, and for every 25,000 compounds investigated in the laboratory, only 25 are tested on humans, and finally 5 of them reach consumers, of which only one is used to obtain revenues for future R\&D investment. ${ }^{4}$ During the 1990s, the sector experienced robust sales growth, roughly $4.4 \%$ annual average, but since then growth has slowed down significantly. For instance, the Office for National Statistics reports that manufacturing fell by $25.9 \%$ between 2009 and 2013 .

Several European countries use some form of price control to reduce total expenditure on prescription drugs. A common tool is the external reference pricing, employed for instance in France, Greece, Ireland, Italy, the Netherlands and Portugal, where the relevant health authority uses the average price from other EU countries to set the maximum reimbursement rate for a branded drug (Kanavos, 2003, Kanavos and Kowal, 2008). The UK, by contrast, does not directly control drug

\footnotetext{
${ }^{4}$ See http://www.ons.gov.uk/ons/rel/iop/index-of-production/april-2014/sty-pharmaceuticals.html and http://www.abpi.org.uk/industry-info/knowledge-hub/uk-economy/Pages/leading-corporations.aspx and http://www.abpi.org.uk/industry-info/future/Pages/default.aspx..
} 
prices, but instead regulates profit on sales of branded drugs to the National Health Service (NHS) under its Pharmaceutical Price Regulation Scheme (PPRS). The scheme, which was initially introduced in 1957, has evolved over the years, but as of 1986 it applies only to the branded drugs. Under the PPRS, the terms of which are negotiated roughly every five years between the Department of Health (DH) and the representatives of the industry via ABPI (1999, 2003, 2009 and 2014 in recent years), firms are free to set prices of branded drugs, which the NHS will reimburse, but the scheme caps the overall return on capital for research active pharmaceutical firms (Kanavos, 2003, Habl et al., 2006, Vogler et al., 2009). Manufactures can introduce new drugs at a price set by them rather than pre-approved by the DH. However, price increases for existing branded drugs need to be justified and approved by the DH. Generics and branded generics are exempt from the PPRS scheme. ${ }^{5}$ As such, generic companies are also free to set any price, but the reimbursement to the pharmacist from the NHS is based on an internal price referencing; the reimbursement rate, called the Drug Tariff, is updated and published every month by the DH and is based on the average price of a basket of generic drugs from different manufacturers and wholesalers.

We use the 2003-2014 British Pharmaceutical Index (BPI) data series by Intercontinental Marketing Services (IMS), which provides monthly sales figures at the package level for all drugs sold in the UK. The BPI data set contains information in terms of total shipments by nominal sales value and various measures of quantity from wholesalers to retail pharmacies and dispensing doctors, but does not include direct sales from manufacturers to hospitals or to non-pharmacy stores (e.g. grocery stores). Individual drugs in the data are identified by manufacturer, product name, and pack variation. The data also includes information on main/active molecule(s), strength and form, as well as if the drug is branded or generic, over the counter or prescription, and if it is reimbursable by NHS or not. We restricted our analysis to prescription drugs covered by the NHS, i.e. overthe-counter (OTC) or non-reimbursable drugs were excluded as these would be sold outside of pharmacies as well, and we do not have complete sales data on those drugs.

For each individual item at the pack level, the data set lists the associated four-digit anatomical therapeutic chemical code (ATC4) and three-digit new form classification code (NFC3). The ATC codes allow drugs to be classified by active ingredients and are further refined by anatomical, therapeutic, pharmacological and the chemical subgroups, while the NFC codes provide information on various forms of the drug, e.g., tablet, capsule, extended release, liquid, cream etc. ${ }^{6}$ In our analysis, we use the four digit ATC classification to define a 'business unit', and NFC codes to

\footnotetext{
${ }^{5}$ In the current context, 'branded generics' are off-patent drugs for which the manufacturer, who was not the originator, has applied for a brand name.

${ }^{6}$ For instance, the first ATC4 letter defines the anatomical group, e.g. $\underline{\mathrm{C}}$ denotes the 'cardiovascular system' while the second group of digits indicates the therapeutic subgroup, e.g. C 03 is for 'diuretics'. The third entry is again a letter and captures the pharmacological subgroup, thus, C03드 stands for 'high-ceilings diuretics' and finally the fourth digit indicates the chemical subgroup, for example C03C트 are 'sulfonamides'.
} 
differentiate among various products within a business unit. Thus we aggregate monthly sales data from individual drugs at the pack level to ATC4 classification by manufacturer and quarter. For example, acid pump inhibitors (A02B2) and psychostimulants (N06B0) produced by Novartis are treated as two separate business units $(\mathrm{BU})$ and in our analysis we compare the change in total sales for each of these business units over time. The final sample consists of sales data from 218 pharmaceutical firms operating in 386 different ATC4 classes spanning across 2,092 business units observed over 40 quarters (Q2 2003 to Q1 2013) for a total of 56,171 observations. ${ }^{7}$ All sales figures are adjusted for inflation using the consumer price index as deflator with base period set to second quarter of 2003. As seen in Table 1, due to entry and exit of firms, business units over time do not constitute a balanced panel.

TABle 1. Sample size and total sales by year

\begin{tabular}{lcccc}
\hline year & Firms & $\begin{array}{c}\text { Classes } \\
(\text { ATC4s })\end{array}$ & $\begin{array}{c}\text { Business } \\
\text { Units (BU) }\end{array}$ & $\begin{array}{c}\text { Total } \\
\text { Sales (in MM) }\end{array}$ \\
\hline $2003(\mathrm{Q} 2+)$ & 139 & 345 & 1,441 & 6,061 \\
2004 & 143 & 345 & 1,465 & 8,441 \\
2005 & 143 & 343 & 1,444 & 7,861 \\
2006 & 146 & 342 & 1,463 & 7,812 \\
2007 & 149 & 348 & 1,459 & 7,815 \\
2008 & 152 & 352 & 1,476 & 7,474 \\
2009 & 158 & 352 & 1,482 & 7,387 \\
2010 & 174 & 355 & 1,509 & 7,332 \\
2011 & 174 & 355 & 1,527 & 7,057 \\
2012 & 174 & 351 & 1,538 & 6,603 \\
$2013($ Q1) & 176 & 351 & 1,508 & 1,560 \\
${ }^{\dagger}$ All figures adjusted by CPI (base Q2 2003). & \\
\hline
\end{tabular}

Consistent with other industry reports of a slow down in manufacturing, our data shows that revenues dropped by 22 percent during the 2004-2012 period, while the number of firms has increased by a similar proportion. The decay of real revenues over time may be an indication of the efficacy of cost effectiveness policies implemented by the NHS, such as promotion of generic drugs, expansion of parallel import, etc. or a reflection of greater competition in the industry leading to lower prices. However, the number of classes and business units do not vary much over time. ${ }^{8}$

We also extracted information on total number of products and packs per product by business unit. To be clear, a product is defined as the unique combination of molecules in a specific form

\footnotetext{
${ }^{7}$ The BPI does not separately identify all generic manufactures and hence within each ATC4 class multiple generic manufactures are treated as one firm.

${ }^{8}$ Though such information is not included in the table, about 77 percent of the classes are observed for all time periods, versus 43.5 percent only for firms. Because of the high turnover of firms and the low turnover of classes, the number of firms in a year is about half that of the classes.
} 
(tablet, extended release, liquid, gel, etc.) by a given firm within an ATC4 class. For instance, Adderall and Adderall XR by Shire Plc. would be counted as two different products by this firm in its psychostimulants business unit (N06BA). Similarly, for a given product, packs can vary either by size (28 pill pack vs 14 pill pack) or by strength (100MG vs 250MG) and after counting total number of packs per product, we define pack variety as the total number of packs aggregated over all products within the BU minus the total number of products, and hence our pack variety measure starts at zero (since every product must come in at least one pack type).

FiguRE 1. Products, varieties and sales per businesses unit

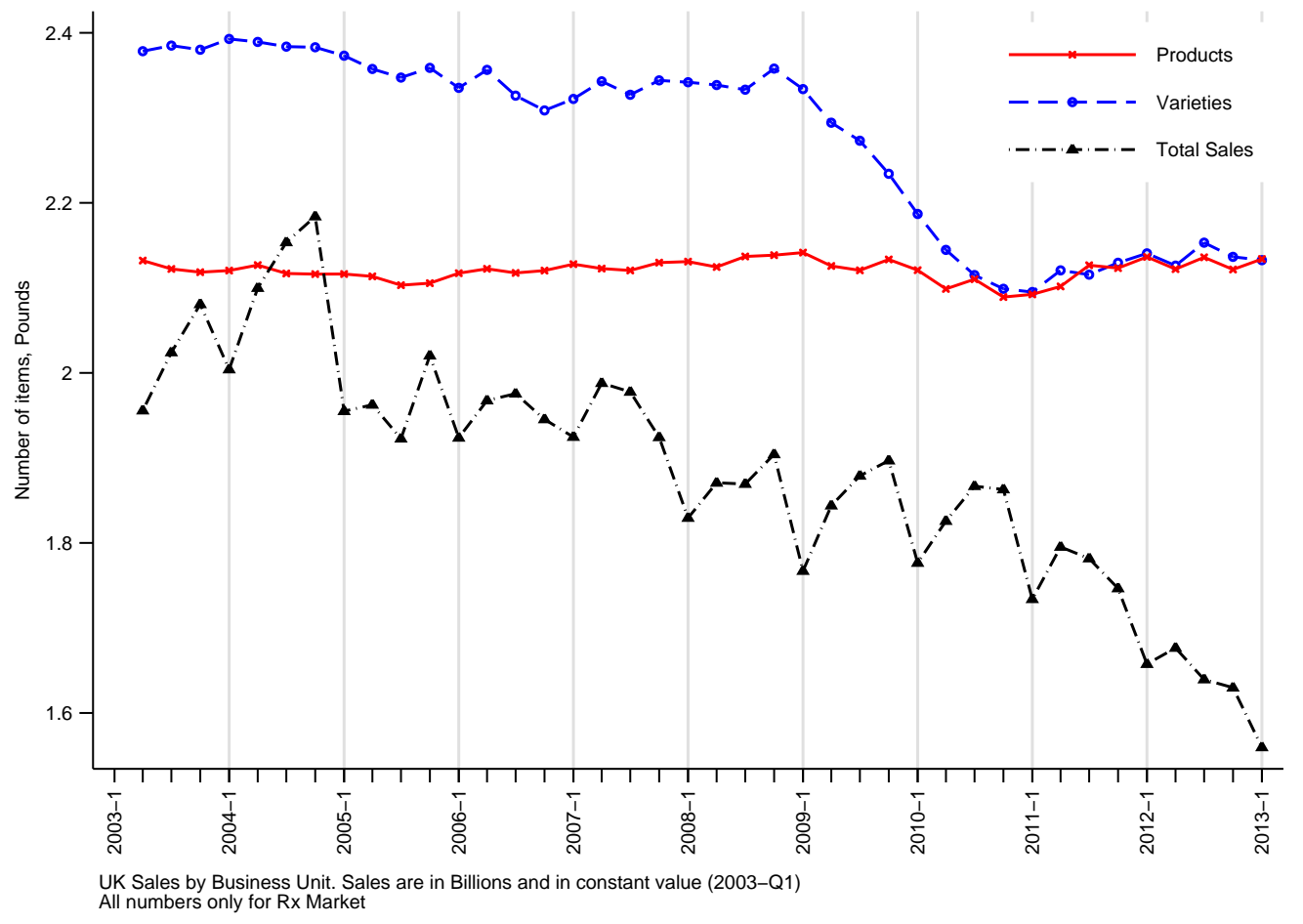

Figure (1) shows the average value of aggregate sales per BU, where the aggregate is over all products and packs related to the business unit, and the average is over all BUs. As noted earlier, real total sales declined over the period and number of business units grew (due to entry), which makes the decline in sales per BU even more drastic. There is also some evidence of seasonality in sales. The figure also shows the average number of product and pack varieties per BU. While the average number of products per BU is stable around 2.1, there is a sharp decline in the number of pack varieties starting with 2009 and continues for the next two years until it settles to a new steady state value. While this decline in the number of pack varieties coincides with the global financial crisis, we did not observe a similar decline in pack varieties in the OTC and non-NHS reimbursable drugs (recall we also have data on those drugs but are not using it in this analysis). The start of 
the decline however does coincide with the last PPRS update in the observation period which was negotiated end of 2008 and was effective for the 2009-2013 period.

TABLE 2. Sales by product and variety ${ }^{\dagger}$

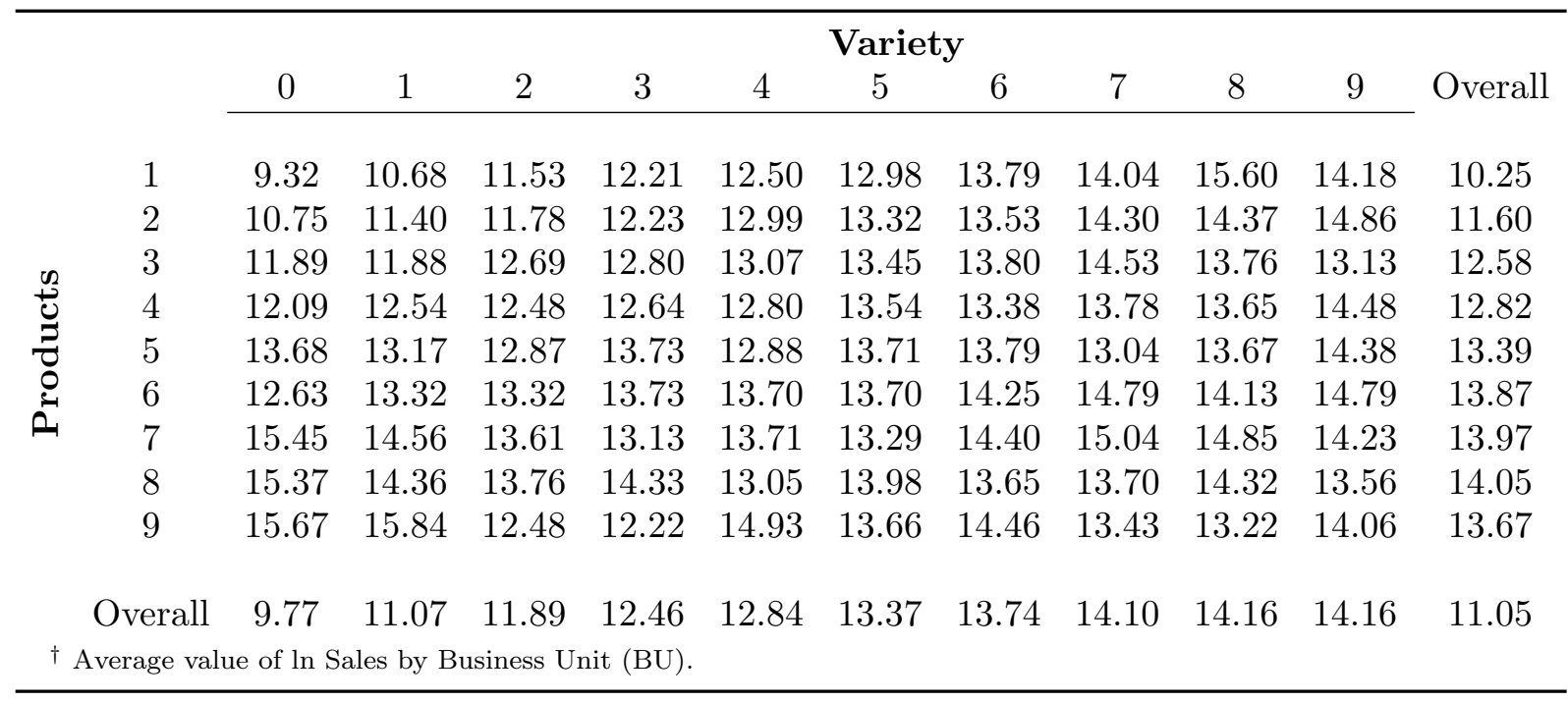

While the figure above provides a snapshot of variation in average sales and products and pack varieties over time, it masks the large variation across BUs and does not show the correlation among these key variables. Instead, table (2) provides a snapshot of the relationship between (log) revenues and number of products and varieties. A very strong positive correlation between revenue and products/varieties is apparent from the table. Generally BUs with more products or pack varieties have greater sales (see the last row or last column of the table) as does holding product or varieties constant and increasing the other variable (movement along any given row/column). The table also highlights some important nonlinearities. For low values of products an increase in the number of varieties leads to larger revenues, a pattern which is shared also by varieties if we were to look at low values of varieties and an increase in the number of products. However, when the number of products (or varieties) is large, an increase in the number of varieties (products) causes a drop in total revenues. This non-monotonicity suggests an interesting nonlinearity in the relationship between revenues and number of products and varieties, which we aim to capture with an interaction term in our econometrics.

In terms of growth, defined as the change in log sales, we find significant variation by the size of the business unit. Figure 2 plots the natural logarithm of sales in period $t$ against the one period lagged value of the same variable. Values along the 45 degree line indicate absence of growth for the $\mathrm{BU}$ while those above the line show positive growth. Interestingly, the variation is larger for middle level of sales. On average, small sized BUs (approximately log sales $<9$ ) grow more than large sized BUs (approximately log sales > 14), but there is also greater variation in growth for smaller business units. 
FiguRE 2. Log-log scatter plot of revenues

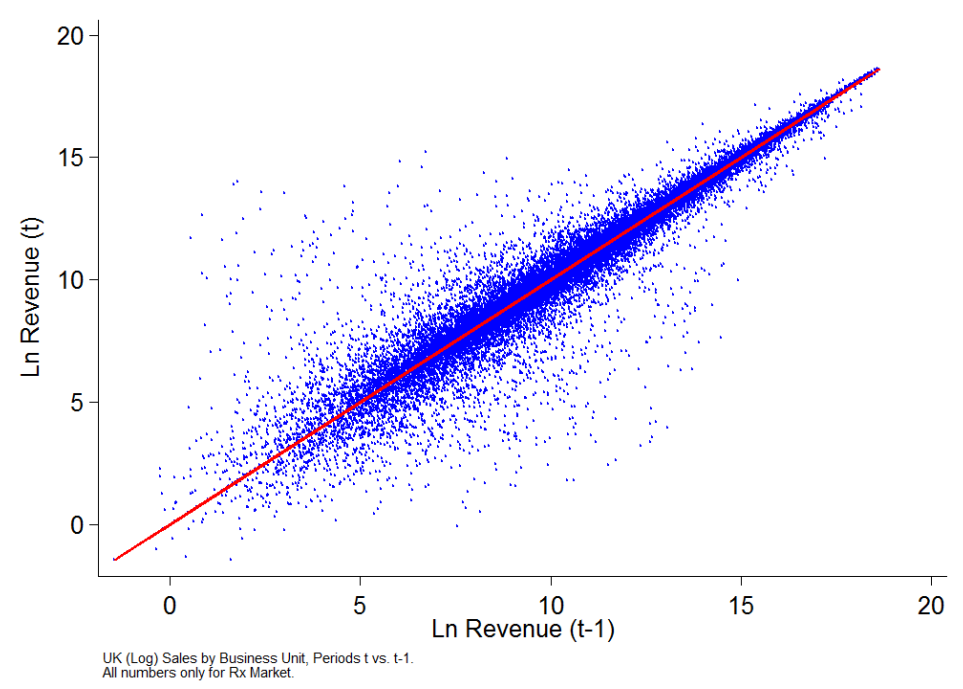

Table 3 provides summary statistics for all the main variables of interest in our empirical model. Consistent with the earlier descriptive statistics, the average BU growth over the ten year period is -0.02 , while the average size of a business unit is 11.26 on the log sales scale (corresponding to $£ 1.34$ million per quarter). However there is significant variation in both growth and size of BUs cross-sectionally (between BUs ) as well as over time (within BUs) but for growth, the variation is larger over time than cross-sectionally (within SD is 0.71 and between SD is 0.42 ). In fact, outside of growth itself, between variation is larger for all variables of interest relative to variation over time. In terms of the structure, while the average number of products and varieties per BU are 2.12 and 2.27, the same two variables at the class level are 8.6 and 9.27, implying that there must be roughly three additional firms with an average of two products each competing with any given BU. The lower part of the table confirms this and shows that on average there are 4.09 firms per ATC4 class. The inter-class competition ranges from a monopoly to up to 29 different firms offering their products in the same class of drugs. In terms of the herfindhal index, which ranges from .13 to 1 with an average value of .69 and a cross-sectional SD of 0.1 , the UK pharmaceutical industry for the prescription drug market appears fairly concentrated at the 4 digit ATC level. Nonetheless, about $32 \%$ of business units face some form of competition from parallel importers for one of their own products, and about $23 \%$ of BUs offer some generic product.

\section{EMPiRical SPECIFICATion}

As our point of entry we use the "spokes model" developed by Chen and Riordan (2007) to study business unit growth under an oligopoly framework that deals with introduction of new products and packs. Allowing for an arbitrary number of possible product varieties and firms, the spokes 
TABLE 3. Summary statistics (within and between variation)*

\begin{tabular}{|c|c|c|c|c|c|c|}
\hline Variable & & Mean & $\mathrm{SD}^{\dagger}$ & Min & Max & $\mathrm{Obs}^{\ddagger}$ \\
\hline \multicolumn{7}{|c|}{ Business Unit level variables } \\
\hline $\begin{array}{l}\text { Growth } \\
(\Delta \ln \text { Sales })\end{array}$ & $\begin{array}{l}\text { overall } \\
\text { between } \\
\text { within }\end{array}$ & -0.02 & $\begin{array}{l}0.73 \\
0.42 \\
0.71\end{array}$ & $\begin{array}{l}-9.26 \\
-3.76 \\
-8.89\end{array}$ & $\begin{array}{r}12.21 \\
3.74 \\
13.59\end{array}$ & $\begin{array}{r}53,258 \\
1,960 \\
27.17\end{array}$ \\
\hline $\begin{array}{l}\text { Size } \\
\text { (ln Sales) }\end{array}$ & $\begin{array}{l}\text { overall } \\
\text { between } \\
\text { within }\end{array}$ & 11.26 & $\begin{array}{l}2.99 \\
3.28 \\
1.20\end{array}$ & $\begin{array}{l}-1.46 \\
-0.21 \\
-0.47\end{array}$ & $\begin{array}{l}18.63 \\
18.25 \\
17.75\end{array}$ & $\begin{array}{r}56,070 \\
2,090 \\
26.83\end{array}$ \\
\hline Products & $\begin{array}{l}\text { overall } \\
\text { between } \\
\text { within }\end{array}$ & 2.12 & $\begin{array}{l}2.29 \\
1.89 \\
0.57\end{array}$ & $\begin{array}{r}1.00 \\
1.00 \\
-6.28\end{array}$ & $\begin{array}{l}31.00 \\
27.53 \\
10.72\end{array}$ & $\begin{array}{r}56,171 \\
2,092 \\
26.85\end{array}$ \\
\hline Variety & $\begin{array}{l}\text { overall } \\
\text { between } \\
\text { within }\end{array}$ & 2.27 & $\begin{array}{l}4.40 \\
3.61 \\
1.23\end{array}$ & $\begin{array}{r}0.00 \\
0.00 \\
-18.10\end{array}$ & $\begin{array}{l}59.00 \\
52.08 \\
26.90\end{array}$ & $\begin{array}{r}56,171 \\
2,092 \\
26.85\end{array}$ \\
\hline $\begin{array}{l}\text { Parallel Imports } \\
\text { (sales proportion) }\end{array}$ & $\begin{array}{l}\text { overall } \\
\text { between } \\
\text { within }\end{array}$ & 0.32 & $\begin{array}{l}0.47 \\
0.38 \\
0.22\end{array}$ & $\begin{array}{r}0.00 \\
0.00 \\
-0.65\end{array}$ & $\begin{array}{l}1.00 \\
1.00 \\
1.30\end{array}$ & $\begin{array}{r}56,171 \\
2,092 \\
26.85\end{array}$ \\
\hline $\begin{array}{l}\text { Generics } \\
\text { (sales proportion) }\end{array}$ & $\begin{array}{l}\text { overall } \\
\text { between } \\
\text { within }\end{array}$ & 0.23 & $\begin{array}{l}0.42 \\
0.40 \\
0.10\end{array}$ & $\begin{array}{r}0.00 \\
0.00 \\
-0.74\end{array}$ & $\begin{array}{l}1.00 \\
1.00 \\
1.20\end{array}$ & $\begin{array}{r}56,171 \\
2,092 \\
26.85\end{array}$ \\
\hline \multicolumn{7}{|c|}{ Class level (ATC4) variables } \\
\hline Products & $\begin{array}{l}\text { overall } \\
\text { between } \\
\text { within }\end{array}$ & 8.60 & $\begin{array}{r}12.75 \\
12.13 \\
1.88\end{array}$ & $\begin{array}{r}1.00 \\
1.00 \\
-9.55\end{array}$ & $\begin{array}{r}131.00 \\
109.40 \\
32.45\end{array}$ & $\begin{array}{r}13,720 \\
386 \\
35.54\end{array}$ \\
\hline Variety & $\begin{array}{l}\text { overall } \\
\text { between } \\
\text { within }\end{array}$ & 9.27 & $\begin{array}{r}20.34 \\
19.05 \\
3.83\end{array}$ & $\begin{array}{r}0.00 \\
0.00 \\
-34.28\end{array}$ & $\begin{array}{r}218.00 \\
170.70 \\
62.57\end{array}$ & $\begin{array}{r}13,720 \\
386 \\
35.54\end{array}$ \\
\hline $\begin{array}{l}\text { Herfindahl } \\
\text { Index (HHI) }\end{array}$ & $\begin{array}{l}\text { overall } \\
\text { between } \\
\text { within }\end{array}$ & 0.69 & $\begin{array}{l}0.28 \\
0.26 \\
0.10\end{array}$ & $\begin{array}{l}0.13 \\
0.16 \\
0.19\end{array}$ & $\begin{array}{l}1.00 \\
1.00 \\
1.23\end{array}$ & $\begin{array}{r}13,717 \\
385 \\
35.63\end{array}$ \\
\hline $\begin{array}{l}\text { Number } \\
\text { of Firms }\end{array}$ & $\begin{array}{l}\text { overall } \\
\text { between } \\
\text { within }\end{array}$ & 4.09 & $\begin{array}{l}3.85 \\
3.68 \\
0.76\end{array}$ & $\begin{array}{r}1.00 \\
1.00 \\
-0.57\end{array}$ & $\begin{array}{r}29.00 \\
25.58 \\
8.44\end{array}$ & $\begin{array}{r}13,720 \\
386 \\
35.54\end{array}$ \\
\hline
\end{tabular}

${ }^{*}$ Variation over time or a given individual is called within $(W)$ variation, and variation across individuals (cross-section) is called between (B). Statistics for within are computed by transforming the data by subtracting out the group mean and adding back in the overall mean.

${ }^{\dagger}$ The overall variation can be approximately expressed as $s_{O}^{2} \simeq s_{W}^{2}+s_{B}^{2}$, where each component is computed as follows: $s_{W}^{2}=\frac{1}{\sum_{i} T_{i}} \sum_{i} \sum_{t}\left(x_{i t}-\bar{x}_{i}\right)^{2} ; s_{B}^{2}=\frac{1}{M-1} \sum_{i}\left(\bar{x}_{i}-\bar{x}\right)^{2}$; $s_{O}^{2}=\frac{1}{\sum_{i} T_{i}} \sum_{i} \sum_{t}\left(x_{i t}-\bar{x}\right)^{2}$.

${ }^{\ddagger}$ Observations are listed as overall $(M)$, over number of BUs $(m)$ for between, and average number over time per BU $(\bar{T})$ for within.

model extends the classical Hotelling duopoly framework (as discussed in Anderson et al., 1992) and develops a spatial model of localized competition to analyze firm performance due to entry of new firms or additional varieties of the products. This framework is characterized by the presence of $n$ single-product firms offering $N$ varieties (where $N \geq n$ ) located in unitary lines, with consumers placed over spokes of constant length terminating towards a common centre. Consumers can buy from any firm regardless of their location on a given spoke. If a firm is not located in the same 
spoke as a consumer, then the consumer has to travel passing by the centre of the market (i.e. of the spokes) to reach the other firm's product. Consumers value product characteristics and they can choose which product to buy according to the rank of their preferences, but they can buy either their first or second most preferred brand. The model provides a (static) equilibrium profit as a non-monotonic function of number of firms and varieties (see equation 5 in Chen and Riordan (2007)). As an approximation, we can think of our business unit (as opposed to the pharmaceutical firm itself) as the single-product firm of the Chen and Riordan's spoke model, and interpret their 'variety' measure as our count of products and packs within the BU. Thus, in a panel setting, we estimate the effect of products and packs on business unit revenue growth (rather than profit which we do not observe) while controlling for number of firms in the business unit, as well as for differences in other observables.

Specifically, let $g_{f c t} \equiv\left(\ln R_{f c t}-\ln R_{f c t-1}\right)$ denote the revenue growth for firm $f$ in anatomical class $c$ between period $t$ and $t-1$, and where $f \in \mathcal{F}$ and $c \in \mathcal{C}$ represent an element of the set of firms and classes. To simplify the notation define $b \equiv f c$ to represent a business unit. Then we model the growth equation by an autoregressive distributed lag specification with $M$ lags of the dependent variable and up to $L$ lags of the time varying strategic variables (products and varieties) as

$$
\begin{aligned}
g_{b t} & =\sum_{m=1}^{M} \gamma_{m} g_{b(t-m)}+\sum_{l=0}^{L}\left(\beta_{1 l} p_{b(t-l)}+\beta_{2 l} v_{b(t-l)}+\beta_{3 l} p_{b(t-l)} v_{b(t-l)}\right) \\
& +\theta_{1} s_{b(t-1)}+\mathbf{x}_{b t} \boldsymbol{\theta}_{2}+\mathbf{x}_{c t} \boldsymbol{\theta}_{3}+u_{t}+\alpha_{b}+\varepsilon_{b t}, \quad t=L+1, \ldots, T, \quad L \geq M .
\end{aligned}
$$

In the equation above the business unit growth in period $t$ is a linear function of lagged growth (with $M$ lags), current and past values of number of products and pack varieties per product $(p, v$ and their interactions up to $L$ lags) and where the latter variables are potentially endogenous. In the final specification we set $M=1$ and $L=4$. The specification also includes other relevant variables, prominently the one period lagged size $\left(s_{b, t-1}\right)$, which we capture with the lagged natural log of revenue. We also include other class-time varying variables such as the number of firms, Herfindahl index, and lagged values of number of products and pack varieties at the class level in the vector $\mathbf{x}_{c t}$ and incorporate additional exogenous controls that vary at the BU level in $\mathbf{x}_{b t}$ (specifically dummy variables to indicate if the business unit has sales due to generic products and if its products are available via parallel imports in the $\mathrm{UK}$ ). A feature of our data is that the cardinality of $\mathcal{C}$ is larger than that of $\mathcal{F}$ which in turn is larger than the number of time periods $T$. Hence, asymptotics rely on the class dimension. For short panels it is common to let the time effect be fixed, here given by $u_{t}$ and hence we exclude it from the composite error term, which is given by the sum of the business unit unobserved heterogeneity, $\alpha_{b}$, and the pure idiosyncratic error term, $\varepsilon_{b t}$.

We assume the idiosyncratic error to be serially uncorrelated and uncorrelated across ATC4 classes. Because of the presence of a lagged dependent variable we follow the dynamic linear panel model 
literature and take a first difference of equation (1) to remove inconsistencies of the parameters associated to the various lags of the dependent variable. Thus we estimate the growth equation above in first difference form and given by

$$
\begin{aligned}
\Delta g_{b t}= & \sum_{m=1}^{M} \gamma_{m} \Delta g_{b(t-m)}+\sum_{l=0}^{L}\left[\beta_{1 l} \Delta p_{b(t-l)}+\beta_{2 l} \Delta v_{b(t-l)}+\beta_{3 l} \Delta\left(p_{b(t-l)} v_{b(t-l)}\right)\right] \\
& +\theta_{1} \Delta s_{b(t-1)}+\Delta \mathbf{x}_{b t} \boldsymbol{\theta}_{2}+\Delta \mathbf{x}_{c t} \boldsymbol{\theta}_{3}+\tau_{t}+\Delta \varepsilon_{b t} .
\end{aligned}
$$

While the first difference form eliminates the unobserved heterogeneity specified earlier as $\alpha_{b}$ term, it is worth noting that by using a first difference estimator we also rule out estimating the effect of any non-time varying factors such as the age of the business unit which may be important (see for instance Cabral and Mata, 2003).

Instruments. The first difference equation cannot be estimated consistently by OLS since now $\Delta \varepsilon_{b t}=\varepsilon_{b t}-\varepsilon_{b(t-1)}$ is correlated with $\Delta g_{b(t-1)}=g_{b(t-1)}-g_{b(t-2)}$ because $g_{b(t-1)}$ depends on $\varepsilon_{b(t-1)}$ per the initial specification. Note that this source of endogeneity is in addition to the potential endogeneity due to products and variety variables on the right hand side which may cause $E\left(\Delta p_{b(t-l)}, \Delta \varepsilon_{b t}\right) \neq 0$ and $E\left(\Delta v_{b(t-l)}, \Delta \varepsilon_{b t}\right) \neq 0$, and obviously $E\left(\Delta\left(p_{b(t-l)} \times v_{b(t-l)}\right), \Delta \varepsilon_{b t}\right) \neq 0$, with $l=\{0,1\}$ in the original levels equation. Put simply, products and varieties can be endogenous, for instance, if there is any reverse causality (growth rates determining if new products and varieties are introduced) or if other omitted variables that are responsible for both the introduction of new products and varieties also contribute to the growth of the business unit. Thus, we treat $\Delta g_{b(t-1)}$ as well as $\Delta p_{b t}, \Delta v_{b t}$, their interaction term, and in some specifications their lagged values as endogenous variables.

To identify the effect of an additional drug or variety, as well as that of the lagged growth, lagged size and other variables, we estimate the equation above using instrumental variables. To be valid, the instruments need to be uncorrelated with revenue growth except for a correlation via the other explanatory variables that determine growth, and to be relevant they need to be correlated with the endogenous variables. To this end we use the time series dimension of the panel and obtain instruments for the change in lagged dependent variable by following Anderson and Hsiao (1982). Specifically, for $m=1$, we can instrument $\Delta g_{b(t-1)}$ with $g_{b(t-2)}$ since the latter term is uncorrelated with $\Delta \varepsilon_{b t}$ by construction, and for $m>1$, Anderson and Hsiao propose other lagged dependent variables as instruments for themselves, i.e., that they can be treated as exogenous.

To find valid instruments for products and varieties, we exploit the assumption that the idiosyncratic error is serially uncorrelated and independent across ATC classes and of the multi-class presence of most of the firms in our data. Our identification strategy relies on an implicit assumption that a firms's propensity to introduce additional products and varieties is common across its various 
business units, and hence number of products and varieties will be correlated across BUs, but that any changes in the number of products and varieties in one BU do not not directly affect growth in another BU. Thus, to construct the instrument for number of products for a business unit, which recall is defined as the combination of firm and the four digit ATC class, we compute and use the average value of number of products by the same firm in other related classes, where related is defined as other ATC4 classes within the same two digit ATC classification. Specifically, we instrument $\Delta p_{b t}$ with $\Delta \bar{p}_{-b t}$, where $\bar{p}_{-b t}$ is computed as the firm's average value of $p$ over time and over ATC4 classes within the same ATC2 class excluding the current ATC4 class and current time period. Thus we obtain an instrument that varies by the business unit and time and which can be thought of as the deviation from the BU's long-run steady state average number of products, where the latter is determined at the firm level in related classes. The logic is extended to derive instruments for the lagged values, i.e., $\Delta \bar{p}_{-b(t-1)}$ as instrument for $\Delta p_{b(t-1)}$, as well as for other lagged values of this variable. The instruments for number of pack varieties and its lag values are also constructed in a similar manner. Finally, the instrument for the interaction between number of products and varieties is constructed as the interaction of the instruments for number of product and those for number of varieties (and similarly for any lagged values of the interaction term).

Note that if a firm does not operate in more than one ATC4 class within the ATC2, we cannot construct an instrument for its products and varieties in the manner described above. However, to handle such cases, we can either drop the requirement of going outside the current ATC4 class and just use the average value from other time periods, or alternatively, use the average value from other time periods and any other ATC4 classes (i.e., do not restrict to average from the same ATC2 class assuming the firm operates in some other ATC class). Thus we also experimented with alternative ways of constructing these instruments by averaging the value of products or varieties over all other ATC4 classes rather than just those within the same ATC2 class, or over other time periods except the current time period but the alternative instruments either turned out to be weak (when we went too wide) or were suspect for validity (when we averaged only over other time periods). The main instruments listed here generally performed well when we restricted the sample to BUs that operate in more than one ATC4 class in various statistical tests relating to under and over identification, as well as first-stage weak instruments F-tests.

\section{Results And Discussion}

OLS Estimates. Table 4 provides estimates of select coefficients and marginal effects under alternative specifications of equation (2) while the detailed set of results are given in the appendix. ${ }^{9}$

\footnotetext{
${ }^{9}$ All specifications include dummy variables for year and quarter, if the business unit has any sales due to generic products or due to parallel imports, and class level variables which include one period lag of number of products and varieties by competitors, number of competitors, and of HHI index for the class. These coefficients have been been suppressed in the text but are given in the appendix.
} 
Column (1) lists OLS results from a parsimonious specification that does not include lags of either the dependent variable (growth) or the lags of products and varieties. However this specification includes lagged size, which in contradiction to Gibrat's law of proportionate growth (see also Simon and Bonini, 1958), has a negative and significant coefficient indicating larger growth for smaller business units. This result is also consistent with the growth pattern by firm size noted earlier in Figure 2. Further, the number of products and varieties have positive and significant coefficients and the coefficient on products is roughly twice as large as that on varieties. Because of the interaction term, which is negative and significant (albeit two orders of magnitude smaller), we also provide marginal effects in the lower part of the table: a one unit increase in products is associated with a $32 \%$ increase in growth rate, while a one unit increase in varieties is associated with $15.9 \%$ increase in growth for the BU. ${ }^{10}$

In column (2) we provide OLS estimates of a distributed lagged model of the first difference form, which includes up to four lags of products, varieties, and the interaction of these terms. Due to the addition of these lagged variables to the model, the number of observations drop from $\sim 50 K$ to $\sim 45 K$. Instead of displaying estimated coefficients on each of these 12 lagged terms, we list in Table 4 the sum of the four lags for each of the three variables, along with standard error of the sum of coefficients. ${ }^{11}$ Column (3) also provides OLS estimates on the first difference equation, but now extends the specification to an augmented distributed lagged model that includes four lags of the dependent variable (growth), and where once again, the additional lags are listed by sums of coefficients, and the number of observations further decrease to $\sim 43 K$ due to the addition of these lagged variables to the model.

Note that in moving from a static specification in column (1) to the distributed lagged model in (2) or to a fully dynamic specification in (3), the coefficient on the size of BU does not change by much (from -1.03 to -1.05 and significant). However, the coefficients on contemporaneous values of products, varieties and the interaction term each decrease in magnitude, while the sum of the coefficients of the lagged values for products and varieties take on positive (and significant) values, at least in the sum of these lagged coefficients. Marginal effects are again given in the lower part of the table, but due to the lagged values of the variables in the dynamic growth models, it is possible to estimate long run and short run marginal effects separately. ${ }^{12}$ Observe that the long run marginal

\footnotetext{
${ }^{10}$ For the static model (column (1)), the marginal effect for product is $\partial g_{b t} / \partial p_{b t}=\beta_{10}+\beta_{30} v_{b t}$. We evaluate it at the sample average value of $v_{b t}$ given in Table 3 . The marginal with respect to variety is computed in a similar manner. The standard errors are computed via the 'delta' method.

${ }^{11}$ The standard errors for the sum of the coefficients are computed using the 'delta' method and individual coefficients rather than the sum of these coefficients is given in the full set of results in the appendix.

${ }^{12}$ Column (2) is a distributed lag model and hence the long-run marginal effect with respect to a product is given by $\partial g_{b t} / \partial p_{b t}=\beta_{10}+\beta_{30} v_{b t}+\sum_{j=1}^{4}\left(\beta_{1 j}+\beta_{3 j} v_{b(t-j)}\right)$ while the short run marginal effect is the same expression as the one given for the static model in column (1). Marginal effects with respect to variety are computed in a similar manner. Column (3) is an augmented distributed lag model and long-run marginal effect with respect to product is $\partial g_{b t} / \partial p_{b t}=\left(\beta_{10}+\beta_{30} v_{b t}+\right.$ $\left.\sum_{j=1}^{4}\left(\beta_{1 j}+\beta_{3 j} v_{b(t-j)}\right)\right) /\left(1-\sum_{m=1}^{4} \gamma_{m}\right)$ with an equivalent expression of marginal with respect to variety.
} 
TABLE 4. First difference growth models ${ }^{\dagger}$

\begin{tabular}{|c|c|c|c|c|c|c|c|c|c|}
\hline & \multicolumn{3}{|c|}{ OLS } & \multicolumn{3}{|c|}{ IV } & \multicolumn{3}{|c|}{ (6) By Size (IV) } \\
\hline & (1) & (2) & (3) & (4) & (5) & (6) & $(6 \mathrm{~S})$ & $(6 \mathrm{M})$ & $(6 \mathrm{~L})$ \\
\hline$s_{b, t-1}:$ Lagged size & $\begin{array}{l}-1.03^{a} \\
(0.014)\end{array}$ & $\begin{array}{l}-1.05^{a} \\
(0.016)\end{array}$ & $\begin{array}{l}-1.05^{a} \\
(0.034)\end{array}$ & $\begin{array}{l}-0.77^{a} \\
(0.097)\end{array}$ & $\begin{array}{r}-0.72^{a} \\
(0.12)\end{array}$ & $\begin{array}{l}-0.73^{a} \\
(0.12)\end{array}$ & $\begin{array}{l}-1.06^{a} \\
(0.19)\end{array}$ & $\begin{array}{l}-0.63^{a} \\
(0.22)\end{array}$ & $\begin{array}{l}-0.68^{b} \\
(0.28)\end{array}$ \\
\hline$p_{b t}:$ Products & $\begin{array}{l}0.34^{a} \\
(0.047)\end{array}$ & $\begin{array}{l}0.30^{a} \\
(0.039)\end{array}$ & $\begin{array}{l}0.28^{a} \\
(0.035)\end{array}$ & $\begin{array}{l}0.27^{a} \\
(0.035)\end{array}$ & $\begin{array}{c}0.27^{a} \\
(0.052)\end{array}$ & $\begin{array}{l}0.28^{a} \\
(0.052)\end{array}$ & $\begin{array}{l}1.17^{a} \\
(0.45)\end{array}$ & $\begin{array}{l}0.29^{a} \\
(0.11)\end{array}$ & $\begin{array}{l}0.18^{b} \\
(0.075)\end{array}$ \\
\hline$v_{b t}$ : Varieties & $\begin{array}{l}0.18^{a} \\
(0.021)\end{array}$ & $\begin{array}{l}0.15^{a} \\
(0.017)\end{array}$ & $\begin{array}{l}0.14^{a} \\
(0.015)\end{array}$ & $\begin{array}{l}0.14^{a} \\
(0.015)\end{array}$ & $\begin{array}{l}0.16^{a} \\
(0.025)\end{array}$ & $\begin{array}{l}0.16^{a} \\
(0.025)\end{array}$ & $\begin{array}{c}0.59^{a} \\
(0.18)\end{array}$ & $\begin{array}{l}0.27^{a} \\
(0.054)\end{array}$ & $\begin{array}{l}0.083^{a} \\
(0.028)\end{array}$ \\
\hline $\begin{array}{l}p_{b t} v_{b t}: \text { Interaction } \\
\text { (Products } \times \text { Varieties })\left(\times 10^{-2}\right)\end{array}$ & $\begin{array}{r}-0.85^{a} \\
(0.18)\end{array}$ & $\begin{array}{r}-0.73^{a} \\
(0.14)\end{array}$ & $\begin{array}{r}-0.67^{a} \\
(0.13)\end{array}$ & $\begin{array}{r}-0.65^{a} \\
(0.12)\end{array}$ & $\begin{array}{r}-0.75^{a} \\
(0.20)\end{array}$ & $\begin{array}{l}-0.78^{a} \\
(0.21)\end{array}$ & $\begin{array}{l}-11.0^{b} \\
(5.70)\end{array}$ & $\begin{array}{l}-1.90^{b} \\
(0.82)\end{array}$ & $\begin{array}{l}-0.41^{b} \\
(0.19)\end{array}$ \\
\hline $\begin{array}{l}g_{b, t-1}: \text { Growth } \\
(\operatorname{Lag} 1)\end{array}$ & & & $\begin{array}{c}-0.0058 \\
(0.026)\end{array}$ & $\begin{array}{l}-0.27^{a} \\
(0.095)\end{array}$ & $\begin{array}{r}-0.33^{a} \\
(0.11)\end{array}$ & $\begin{array}{l}-0.33^{a} \\
(0.11)\end{array}$ & $\begin{array}{l}-0.14 \\
(0.17)\end{array}$ & $\begin{array}{l}-0.33 \\
(0.21)\end{array}$ & $\begin{array}{l}-0.21 \\
(0.27)\end{array}$ \\
\hline $\begin{array}{l}\sum_{l=1}^{4} p_{b, t-l}: \text { Products } \\
(\text { Sum of coefficients lags } 1-4)^{\dagger \dagger}\end{array}$ & & $\begin{array}{l}0.195^{a} \\
(0.038)\end{array}$ & $\begin{array}{l}0.192^{a} \\
(0.041)\end{array}$ & $\begin{array}{l}0.111^{b} \\
(0.045)\end{array}$ & $\begin{array}{l}0.153^{c} \\
(0.086)\end{array}$ & $\begin{array}{l}0.153^{a} \\
(0.059)\end{array}$ & $\begin{array}{c}0.773^{b} \\
(0.317)\end{array}$ & $\begin{array}{c}0.171 \\
(0.141)\end{array}$ & $\begin{array}{c}0.066 \\
(0.051)\end{array}$ \\
\hline $\begin{array}{l}\sum_{l=1}^{4} v_{b, t-l}: \text { Varieties } \\
(\text { Sum of coefficients lags } 1-4)^{\dagger \dagger}\end{array}$ & & $\begin{array}{l}0.069^{a} \\
(0.015)\end{array}$ & $\begin{array}{l}0.065^{a} \\
(0.015)\end{array}$ & $\begin{array}{c}0.021 \\
(0.021)\end{array}$ & $\begin{array}{c}0.032 \\
(0.037)\end{array}$ & $\begin{array}{l}0.018 \\
(0.025)\end{array}$ & $\begin{array}{c}0.212 \\
(0.163)\end{array}$ & $\begin{array}{c}0.146 \\
(0.091)\end{array}$ & $\begin{array}{c}0.020 \\
(0.017)\end{array}$ \\
\hline $\begin{array}{l}\sum_{l=1}^{4} p_{b, t-l} v_{b, t-l}: \text { Interaction } \\
\text { (Sum of coefficients lags } 1-4)^{\dagger \dagger}\end{array}$ & & $\begin{array}{r}-0.005^{a} \\
(0.001)\end{array}$ & $\begin{array}{r}-0.005^{a} \\
(0.001)\end{array}$ & $\begin{array}{l}-0.003^{b} \\
(0.001)\end{array}$ & $\begin{array}{l}-0.005^{c} \\
(0.003)\end{array}$ & $\begin{array}{l}-0.005^{b} \\
(0.002)\end{array}$ & $\begin{array}{l}-0.056^{c} \\
(0.032)\end{array}$ & $\begin{array}{l}-0.015 \\
(0.012)\end{array}$ & $\begin{array}{l}-0.002^{c} \\
(0.001)\end{array}$ \\
\hline \multirow[t]{2}{*}{$\begin{array}{l}\sum_{m=2}^{4} g_{b, t-m}: \text { Growth } \\
(\text { Sum of coefficients lags } 2-4)^{\dagger \dagger}\end{array}$} & & & $\begin{array}{c}-0.286^{a} \\
(0.066)\end{array}$ & $\begin{array}{l}-0.663^{a} \\
(0.164)\end{array}$ & $\begin{array}{c}-0.857^{a} \\
(0.186)\end{array}$ & $\begin{array}{l}-0.854^{a} \\
(0.184)\end{array}$ & $\begin{array}{c}-0.762^{a} \\
(0.204)\end{array}$ & $\begin{array}{l}-0.681^{c} \\
(0.376)\end{array}$ & $\begin{array}{l}-0.452 \\
(0.383)\end{array}$ \\
\hline & \multicolumn{9}{|c|}{ Marginal effects of products and varieties } \\
\hline Products (Short run) & & $\begin{array}{l}0.285^{a} \\
(0.037)\end{array}$ & $\begin{array}{l}0.201^{a} \\
(0.025)\end{array}$ & $\begin{array}{l}0.131^{a} \\
(0.017)\end{array}$ & $\begin{array}{l}0.114^{a} \\
(0.022)\end{array}$ & $\begin{array}{l}0.119^{a} \\
(0.022)\end{array}$ & $\begin{array}{l}0.562^{a} \\
(0.211)\end{array}$ & $\begin{array}{l}0.130^{a} \\
(0.049)\end{array}$ & $\begin{array}{l}0.098^{b} \\
(0.04)\end{array}$ \\
\hline Products (Long run) & $\begin{array}{l}0.320^{a} \\
(0.044)\end{array}$ & $\begin{array}{l}0.467^{a} \\
(0.053)\end{array}$ & $\begin{array}{l}0.340^{a} \\
(0.042)\end{array}$ & $\begin{array}{l}0.185^{a} \\
(0.029)\end{array}$ & $\begin{array}{l}0.178^{a} \\
(0.049)\end{array}$ & $\begin{array}{c}0.183^{a} \\
(0.041)\end{array}$ & $\begin{array}{l}0.941^{a} \\
(0.349)\end{array}$ & $\begin{array}{l}0.205^{b} \\
(0.09)\end{array}$ & $\begin{array}{l}0.131^{b} \\
(0.053)\end{array}$ \\
\hline Varieties (Short run) & & $\begin{array}{l}0.134^{a} \\
(0.015)\end{array}$ & $\begin{array}{l}0.098^{a} \\
(0.010)\end{array}$ & $\begin{array}{l}0.064^{a} \\
(0.007)\end{array}$ & $\begin{array}{l}0.067^{a} \\
(0.010)\end{array}$ & $\begin{array}{l}0.067^{a} \\
(0.010)\end{array}$ & $\begin{array}{l}0.229^{a} \\
(0.057)\end{array}$ & $\begin{array}{l}0.116^{a} \\
(0.022)\end{array}$ & $\begin{array}{l}0.042^{a} \\
(0.013)\end{array}$ \\
\hline Varieties (Long run) & $\begin{array}{l}0.159^{a} \\
(0.019)\end{array}$ & $\begin{array}{l}0.191^{a} \\
(0.021)\end{array}$ & $\begin{array}{l}0.140^{a} \\
(0.017)\end{array}$ & $\begin{array}{l}0.071^{a} \\
(0.012)\end{array}$ & $\begin{array}{l}0.077^{a} \\
(0.021)\end{array}$ & $\begin{array}{l}0.070^{a} \\
(0.017)\end{array}$ & $\begin{array}{l}0.299^{b} \\
(0.116)\end{array}$ & $\begin{array}{l}0.176^{a} \\
(0.049)\end{array}$ & $\begin{array}{c}0.049^{a} \\
(0.019)\end{array}$ \\
\hline $\begin{array}{l}\text { Observations } \\
\text { R-squared }\end{array}$ & $\begin{array}{l}50,942 \\
0.535\end{array}$ & $\begin{array}{l}44,893 \\
0.514\end{array}$ & $\begin{array}{c}42,994 \\
0.513\end{array}$ & $\begin{array}{c}42,994 \\
0.507\end{array}$ & $\begin{array}{c}23,054 \\
0.521\end{array}$ & $\begin{array}{c}23,054 \\
0.521\end{array}$ & $\begin{array}{l}5,581 \\
0.624\end{array}$ & $\begin{array}{l}8,334 \\
0.462\end{array}$ & $\begin{array}{l}9,139 \\
0.395\end{array}$ \\
\hline
\end{tabular}

${ }^{\dagger}$ Standard errors are in parenthesis and clustered by business unit (firm-atc4 combination). Superscripts $a, b, c$ indicate significance at $1 \%, 5 \%$ and $10 \%$, respectively. All regressions include additional controls at the class and BU level, as well as indicator variables for year and quarter (see Table A-1 in the appendix for detailed results).

Specification (1) does not include any lags, (2) is a distributed lag model and includes up to four lags of products, varieties and interactions. Specification (3) is an augmented distributed lag model that includes four lags of the dependent variable (i.e., growth). Specification (4) treats only the first lag of growth as endogenous, (5) treats the first lag of growth, as well as products, and varieties, and their interaction and all four lags of each of these as endogenous variables (total 16), and specification (6) treats the first lag of growth and only the contemporaneous values of products, varieties and interaction as endogenous variables (total of 4 endogenous variables). Specifications $(6 \mathrm{~S}),(6 \mathrm{M})$, and $(6 \mathrm{~L})$ are same as $(6)$, but on sub-samples by initial size of business unit being (s)mall, (m)edium and (l)arge.

${ }^{\dagger \dagger}$ For brevity we provide the sum of coefficients of the lagged variables. Individual coefficients for each of the lags is given in the appendix. The standard error on the sum of lagged coefficients is computed using the 'delta' method and accounts for clustering.

$¥ \ddagger$ Marginal effects are computed at the sample mean. The account for the interaction terms, the lagged values of the variable as well as the lagged values of growth. Standard errors are computed using the delta method.

effects in specification (3) are similar to those in the static model, i.e., $34 \%$ and $14 \%$ for products 
and varieties respectively, but the short run boost in revenue from an additional product or variety is $20 \%$ and $9.8 \%$ respectively. ${ }^{13}$

IV Estimates. The next three columns re-estimate the dynamic growth model of (3) under alternative assumptions about the correlation of the error term with some of the right hand side variables. Column (4) shows the results when only the first lagged value of growth is treated as endogenous, and accordingly instrumented for, but all other variables are assumed to be exogenous. The lagged value of growth is treated as endogenous because, as argued earlier, in the first difference form the first lagged value of the dependent variable becomes correlated with the error term by construction. Next, column (5) additionally treats the past and contemporaneous values of products, varieties and their interactions as endogenous, so 16 total endogenous variables, while column (6) treats only the first lagged value of growth and the contemporaneous values of products, varieties and interaction as correlated with the error term and hence only four variables are treated as endogenous in this model. Further, in columns (5) and (6) we restrict the sample to where a BU operates in more than one ATC4 class within the ATC2 due to availability of instruments (recall we construct the instruments for products and varieties for BU as the average value in other classes and over time for the same firm, and hence the value is not available if the firm operates in only one ATC4 class). ${ }^{14}$ For each of the three models, results related to the first stage F-statistics (weak instruments test), under identification and over identification are given in the appendix in table Table A-2. In all cases the first stage F-statistics suggest that the instruments are not weak as the relevant F-values are always above 10, and in all three specifications, the null of under identification is rejected and in models (5) and (6) the null of over identification in not rejected (model 4 is just identified so test is not available). All in all, the statistical tests summarized in table (A-2) lend support to these instruments as valid and relevant.

In terms of the main results, the largest change in estimated parameters and marginal effects comes when we move from column (3), where all variables are treated as exogenous, to column (4) which treats the first lag of the dependent variable as an endogenous variable. The coefficient on the lagged size drops from -1.05 to -0.77 (though still statistically significant) with some appreciable change in the lagged coefficients for products and varieties as well. The change is enough that the estimated long run marginal effects with respect to products and varieties (compute at the sample

\footnotetext{
${ }^{13}$ For the static model in column (1), there is no distinction between short run and long run marginal effects since it is not built into the specification. However, when comparing the results between static and dynamic models (where the latter does have this distinction), we choose to interpret the results from the static model as those corresponding to the long run because, (i) the static model can be seen as an adjustment to long run equilibrium, and (ii) because the static model in (1) can itself be viewed as restricted version of (3) where the additional coefficients on the lags are constrained to be zero and hence the expression for the long run marginal effects in (2) and (3) correspond to the marginal effect in column (1).

${ }^{14}$ An alternative set of instruments discussed earlier is to include BUs that operate within only a single class and to construct instruments using the average value from other time periods. Results from these alternative instruments are qualitatively similar but since their validity is suspect we prefer to restrict the sample to firms that operate in more than one ATC4 class and not use variation over time alone to construct the instruments.
} 
mean) drop to roughly half their previous values, i.e., from $34 \%$ and $14 \%$ in column (3) to $18.5 \%$ and $7.1 \%$ in column (4). The results in the next two columns with either all variables related to products and varieties are endogenous or just their contemporaneous values are endogenous are quite similar. While there is not much difference in the estimated parameters and marginal effects in the three models, we use the specification in (6) as our preferred model to discuss further the marginal effects.

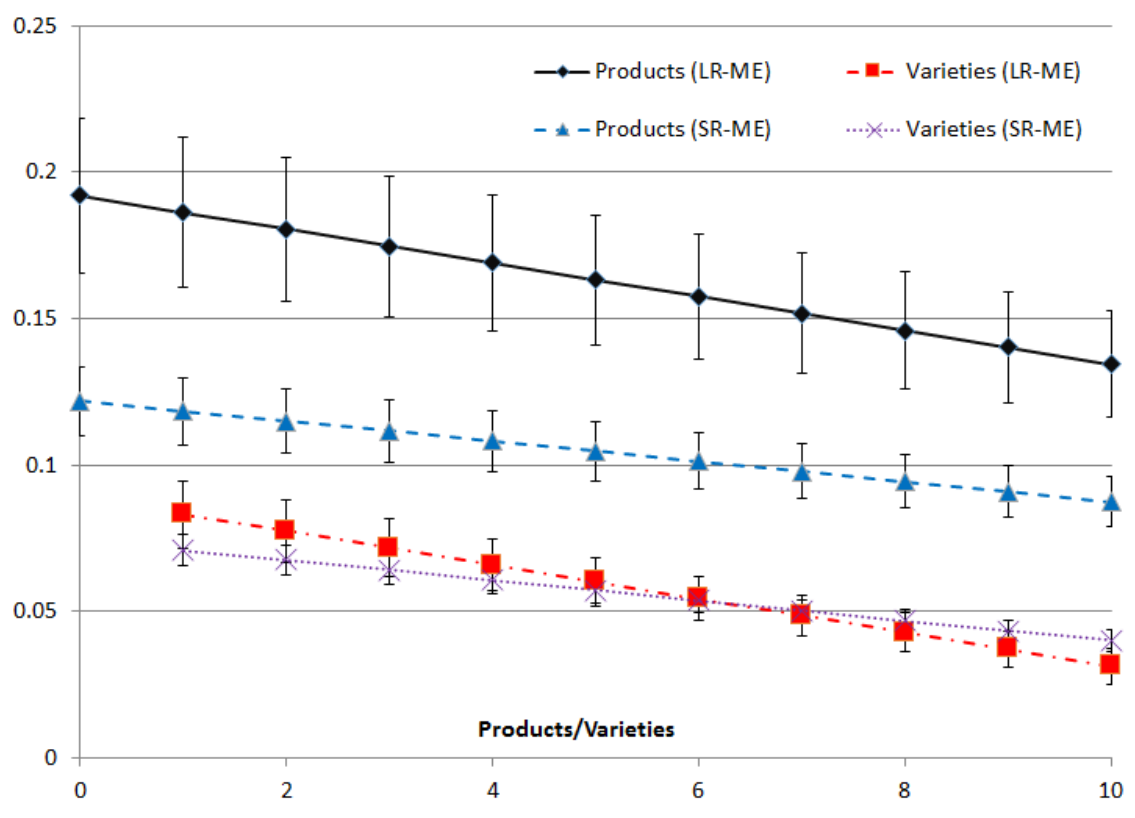

FiguRE 3. Marginal Effects - Products and Varieties

Note that due to the interaction term between products and varieties (which are significant in all models), the marginal effects are not constant. For instance, the marginal effect with respect to products is a function of varieties, and similarly the other way round, and this is true for both the long run and short run marginal effects. While Table 4 above reports these marginal effects at the mean value of the relevant variables (for instance $\partial g / \partial p$ at $\bar{v}$ ), Figure 3 plots the estimated marginal effect of products for a range of observed values of varieties, and similarly the marginal effect of varieties for a range of values of products. The marginal effects are for both the long run and short run, and the vertical error bars are set equal to the estimated standard error.

Each of the four marginal effects are positive and significantly different from zero for a range of observed values of products and varieties (and not just at the sample mean values of 2.12 and 2.27), but equally important, the negative slopes of these graphs imply that the impact on growth from an additional product is smaller if the BU has many pack varieties than if it had fewer pack varieties. Similarly, the marginal with respect to pack varieties is diminishing in products. The figure also show that while there is a (statistical) difference in the long and short run marginal 
effect of additional products, there is virtually none in the long and short run for varieties. In turn, these imply that the boost in sales from additional pack varieties are smaller but more immediate, whereas those from introducing additional products are larger, but also over a longer period of time.

By Size (IV Estimates). So far our analysis controls for size of the business unit but does not allow for the impact of products and varieties on growth to vary by the size of the business unit. To study this effect, one possible extension is to allow for an interaction between (lagged) size and products and varieties so that the marginal effects can vary by size. Instead, due to the richness of our data, we allow for more flexible version by re-estimating specification (6) on separate sub-samples by size, which in turn let all coefficients vary by size, rather than just those related to products and varieties. Columns (6S), (6M) and (6L) in Table 4 display estimates from sub-samples by business unit size classified as small, medium and large respectively, based on their initial size.

Figure 4. Long Run Marginal Effects by Firm Size

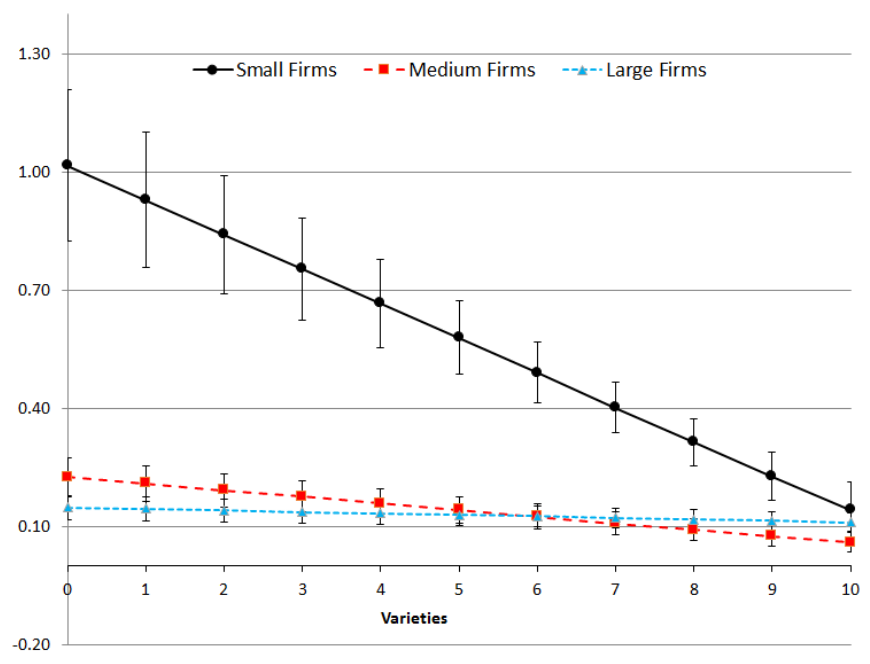

(i) LR Marginal Effect wrt Products

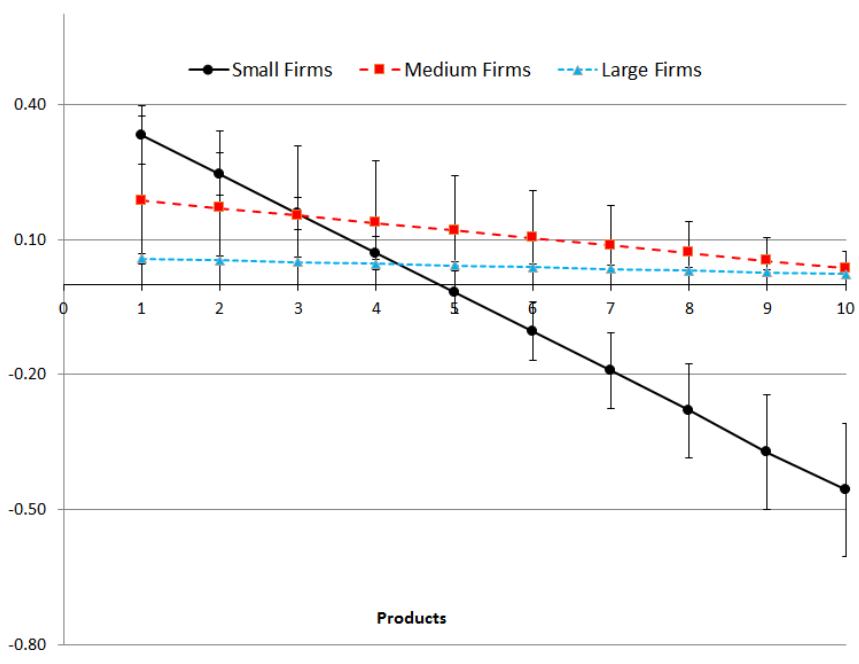

(ii) LR Marginal Effect wrt Varieties

The change in the estimated coefficients for the relevant variables are substantial, both when the comparison is done within the sub-sample of class sizes and when it is set against the entire sample displayed in column (6). Almost all coefficients of interest (lagged size, products, varieties and interactions) increase in magnitude for small business units and decrease for large business units. For instance, in column (6) the coefficient on products is 0.28 but this increases to 1.17 in (6S) and decreases to 0.18 in (6L) (and stays fairly close to the original value for (6M) sample). Similar patterns can be observed for other coefficients. In fact, as Figure 4 shows, the long run marginal effect of new products is positive (and much greater for small BUs than for large BUs) over a wide range of pack varieties. On the other hand, the marginal impact of additional variety on growth is much smaller (and even becomes negative in out of sample projections when a small BU has a large 
number of products) and is not statistically different for small vs large firms. While several studies have found evidence supporting growth by small firms (see for instance Calvo, 2006) or at least for short periods after birth (e.g. Lotti et al., 2003), our results shed insight into this mechanism for growth: the returns in terms of growth from introducing a new product are much larger for small firms than for large firms.

\section{Conclusions}

Pharmaceutical firms often launch additional products within the same therapeutic class or launch additional pack varieties of existing drugs. Additional products are a form of product differentiation while the introduction of an additional pack is perhaps better understood as a non-linear pricing strategy. Previous literature on product introduction, particularly the me-too literature, has focused on consumer welfare and competitive effects of follow-on drugs, while the pricing literature has focused on prices by branded and generic firms pre- and post-patent expiration. We complement those studies by estimating the impact of additional products and pack varieties on growth of a business unit in the long and short run, and classify our results by the size of the business unit.

Primary identification difficulty is that previous period growth may impact both the current period growth as well as any change in the number of products and packs by the business unit or that other unobserved factors may explain change in both the variables. To overcome this issue, we use the lagged values of growth in the specification but also use a firm's propensity to introduce products and packs, as measured by average values of these same variables in other periods and related ATC classes, as instruments for the endogenous variables.

One of our main results is that a new product leads to a 12 per cent growth in the short run and 18 per cent in the long run, whereas a new pack variety only produces a short term effect of about 7 per cent growth with no additional impact over the long run. To the extent that additional products with a narrowly defined anatomical class can be thought of as me-too drugs, we interpret the first result as empirical evidence that innovation is an important driver of firm's (business unit's) growth in the UK pharmaceutical market. Further, strategies of second degree price discrimination such as pack variety, are considered a good alternative to trigger short term growth.

We also find that in the British pharmaceutical sector, smaller business units grew more than the larger ones. Equally importantly, given an existing combination of products and varieties, an additional product may be more profitable vis-a-vis opportunity for growth for the smaller business unit than for larger units. On the other hand, the difference in marginal with respect to pack variety (or price discrimination) by size of business unit is much smaller and the effect is not statistically different by size of the unit. 


\section{REFERENCES}

Anderson, Simon P., Andrè de Palma, and Jacques-Francois Thisse, Discrete choice theory of product differentiation, Cambridge, MA: MIT Press, 1992.

Anderson, Theodore W. and Cheng Hsiao, "Formulation and estimation of dynamic models using panel data," Journal of Econometrics, January 1982, 18 (1), 47-82.

Appelt, Silvia, "Authorized generic entry prior to patent expiry: reassessing incentives for independent generic entry," July 2015, 97 (3), 654-666. The Review of Economics and Statistics.

Arcidiacono, Peter, Paul Ellickson, Peter Landry, and David B. Ridley, "Pharmaceutical followers," International Journal of Industrial Organization, September 2013, 31 (5), 538-553.

Armstrong, Mark and John Vickers, "Competitive price discrimination," RAND Journal of Economics, Winter 2001, 32 (4), 1-27.

Bokhari, Farasat A. S. and Gary M. Fournier, "Entry in the ADHD drugs market: Welfare impact of generics and me-toos," Journal of Industrial Economics, June 2013, 61 (2), 340-393.

Bonanno, Giacomo, "Location choice, product proliferation and entry deterrence," Review of Economic and Studies, January 1987, 54 (1), 37-45.

Bottazzi, Giulio and Angelo Secchi, "Common properties and sectoral specificities in the dynamics of U.S. manufacturing companies," Review of Industrial Organization, December 2003, 23 (3), 217-232.

, Giovanni Dosi, Marco Lippi, Fabio Pammolli, and Massimo Riccaboni, "Innovation and corporate growth in the evolution of the drug industry," International Journal of Industrial Economics, July 2001, 19 (7), 1161-1187.

Cabral, Luís M. B. and José Mata, "On the evolution of the firm size distribution: Facts and theory," American Economic Review, September 2003, 93 (4), 1075-1090.

Calvo, José L., "Testing Gibrat's Law for small, young and innovating firms," Small Business Economic, August 2006, 26 (2), 117-123.

Chen, Yongmin and Michael H. Riordan, "Price and variety in the Spokes model," The Economic Journal, 2007, 117 (522), 897-921.

Comanor, William S., "Research and competitive product differentiation in the pharmaceutical industry in the United States," Economica, November 1964, 31 (124), 372-384.

, "The political economy of the pharmaceutical industry," Journal of Economic Literature, September 1986, 24 (3), 1178-1217.

Danzon, Patricia M., "Price discrimination for pharmaceuticals: Welfare effects in the US and the EU," International Journal of the Economics of Business, May 1997, 4 (3), 301-322.

and Michael F. Furukawa, "Cross-national evidence on generic pharmaceuticals: Pharmacy vs. physician-driven markets," NBER Working Paper w17226, National Bureau of Economic Research July 2011.

de Frutos, Maria-Angeles, Carmine Ornaghi, and Georges Siotis, "Competition in the pharmaceutical industry: How do quality differences shape advertising strategies?," Journal of Health Economics, January 2013, 32 (1), 268285.

Del Monte, Alfredo and Erasmo Papagni, "R\&D and the growth of firms: Empirical analysis of a panel of Italian firms," Research Policy, June 2003, 32 (6), 1003-1014.

Demirel, Pelin and Mariana Mazzucato, "Innovation and firm growth: Is R\&D worth it?," Industry and Innovation, January 2012, 19 (1), 45-62.

DiMasi, Joseph A. and Cherie Paquette, "The economics of follow-on drug research and development: Trends in entry rates and the timing of development," PharmacoEconomics, 2004, 22 (2 (Suppliment 2)), 1-14.

and Laura B. Faden, "Competitiveness in follow-on drug R\&D: a race or imitation?," Nature Reviews Drug Discovery, January 2011, 10 (1), 23-27.

Dunne, Paul and Alan Hughes, "Age, size, growth and survival: UK companies in the 1980s," The Journal of Industrial Economics, June 1994, 42 (2), 115-140.

Ekelund, Mats and Björn Persson, "Pharmaceutical pricing in a regulated market," The Review of Economics and Statistics, May 2003, 85 (2), 298-306. 
Ellison, Glenn and Sara Fisher Ellison, "Strategic entry deterrence and the behavior of pharmaceutical incumbents prior to patent expiration," American Economic Journal: Microeconomics, February 2011, 3 (1), 1-36.

Frank, Richard G. and David S. Salkever, "Pricing patent loss and the market for pharmaceuticals," Southern Economic Journal, October 1992, 59 (2), 165-179.

Freel, Mark S., "Do small innovating firms outperform non-innovators?," Small Business Economics, May 2000, 14 (3), 195-210.

Frijlink, Henderik W., "Benefits of different drug formulations in psychopharmacology," European Neuropsychopharmacology, September 2003, 13 (Suppl), s77-s84.

Geroski, Paul A. and Saadet Toker, "The turnover of market leaders in UK manufacturing industry, 1979-86," International Journal of Industrial Organization, 1996, 14, 141-158.

and Stephen Machin, "Do innovating firms outperform non-innovators?," Business Strategy Review, June 1992, 3 (2), 79-90.

, and Christopher F. Walters, "Corporate growth and profitability," The Journal of Industrial Economics, June 1997, 45 (2), 171-189.

Goozner, Merrill, The $\$ 800$ million pill: The truth behind the cost of new drugs, Berkeley, CA: University of California Press, 2004.

Habl, Claudia, Katja Antony, Danielle Arts, Michael Entleitner, Barbara Fröschl, Christine Leopold, Heidi Stürzlinger, Sabine Vogler, and Marion Weigl, Surveying, assessing and analysing the pharmaceutical sector in the 25 member states, ÖBIG Health Economics, Commissioned by European Union - DG Competition, 2006.

Hall, Bronwyn H., "The relationship between firm size and firm growth in the U.S. manufacturing sector," Journal of Industrial Economics, June 1987, 35 (4), 583-600.

Hollis, Aidan, "Me-too drugs: Is there a problem," December 13 2004. Published by World Health Organization Commission on Intellectual Property Rights, Innovation and Public Health.

_, "Comment on 'The economics of follow-on drug research and development: trends in entry rates and the timing of development'," Pharmacoeconomics, December 2005, 23 (12), 1187-1192.

Kanavos, Panos, "Overview of pharmaceutical pricing and reimbursement regulation in Europe," Japanese Pharmacology and Therapeutics, 2003, 31 (10), 819-838.

and Stacey Kowal, "Does pharmaceutical parallel trade serve the objectives of cost control?," Eurohealth, 2008, 14 (2), 22-26.

Klemperer, Paul, "Competition when consumers have switching costs: An overview with applications to industrial organization, macroeconomics and international trade," Review of Economic Studies, May 1995, 62 (4), 515-539.

and A. Jorge Padilla, "Do firms' product lines include too many varieties?," RAND Journal of Economics, 1997, 28 (3), 472-488.

Kyle, Margaret K., "Strategic responses to parallel trade," The B.E. Journal of Economic Analysis and Policy (Advances), January 2011, 11 (2), 1-32.

Lichtenberg, Frank R. and Tomas J. Philipson, "The dual effects of intellectual property regulations: Within- and between- patent competition in the U.S. pharmaceuticals industry," The Journal of Law and Economics, October 2002, 45 (S2), 643-672.

Lotti, Francesca, Enrico Santarelli, and Marco Vivarelli, "Does Gibrat's Law hold among young, small firms?," Journal of Evolutionary Economics, August 2003, 13 (3), 213-235.

Lu, Z. John and William S. Comanor, "Strategic pricing of new pharmaceuticals," The Review of Economics and Statistics, February 1998, 80 (1), 108-118.

Malueg, David A. and Marius Schwartz, "Parallel imports, demand dispersion, and international price discrimination," Journal of International Economics, November 1994, 37 (3-4), $167-195$.

Mueller, Michael T. and Alexander Frenzel, "Competitive pricing within pharmaceutical classes: evidence on "follow-on" drugs in Germany 1993-2008," The European Journal of Health Economics, 2015, 16 (1), 73-82.

Regan, Tracy L., "Generic entry, price competition, and market segmentation in the prescription drug market," International Journal of Industrial Organization, July 2008, 26 (4), 930-948. 
Scherer, Frederic M., "Pricing, Profits, and Technological Progress in the Pharmaceutical Industry," The Journal of Economic Perspectives, 1993, "7 (3), 97-115.

Handbook of Health Economics, Vol. 1B, Amsterdam, North-Holland: Elsevier, 2000.

Simon, Herbert A. and Charles Bonini, "The size distribution of business firms," American Economic Review, September 1958, 48 (4), 607-617.

Stole, Lars A., "Price discrimination and competition," in M. Armstrong and R. Porter, eds., Handbook of Industrial Organization, Vol. 3, Amsterdam, North-Holland: Elsevier Science Publishers, 2007, chapter 34, pp. 2221-2299.

Varian, Hal R., "Price discrimination," in R. Schmalensee and R.D. Willig, eds., Handbook of Industrial Organization, Vol. 1, Amsterdam, North-Holland: Elsevier Science Publishers, 1989, chapter 10, p. 597654.

, "Price discrimination and social welfare," The American Economic Review, September 1995, 75 (4), 870-875.

Vogler, Sabine, Jaime Espin, and Claudia Habl, "Pharmaceutical pricing and reimbursement information (PPRI) new PPRI analysis including Spain," Pharmaceuticals Policy and Law, 2009, 11 (3), 213-234. 


\section{APPENDIX}

TABlE A-1. FD Growth Models ${ }^{\dagger}$

\begin{tabular}{|c|c|c|c|c|c|c|c|c|c|}
\hline & \multicolumn{3}{|c|}{ OLS } & \multicolumn{3}{|c|}{ IV } & \multicolumn{3}{|c|}{ (6) By business unit size } \\
\hline & $(1)$ & $(2)$ & $(3)$ & $(4)$ & $(5)$ & $(6)$ & $(6 \mathrm{~S})$ & $(6 \mathrm{M})$ & $(6 \mathrm{~L})$ \\
\hline $\begin{array}{l}s_{b, t-1}: \text { Size } \\
\text { (Lagged Size of Bus. Unit) }\end{array}$ & $\begin{array}{l}-1.03^{a} \\
(0.014)\end{array}$ & $\begin{array}{l}-1.05^{a} \\
(0.016)\end{array}$ & $\begin{array}{l}-1.05^{a} \\
(0.034)\end{array}$ & $\begin{array}{l}-0.77^{a} \\
(0.097)\end{array}$ & $\begin{array}{r}-0.72^{a} \\
(0.12)\end{array}$ & $\begin{array}{r}-0.73^{a} \\
(0.12)\end{array}$ & $\begin{array}{r}-1.06^{a} \\
(0.19)\end{array}$ & $\begin{array}{l}-0.63^{a} \\
(0.22)\end{array}$ & $\begin{array}{l}-0.68^{b} \\
(0.28)\end{array}$ \\
\hline$p_{b t}:$ Products & $\begin{array}{l}0.34^{a} \\
(0.047)\end{array}$ & $\begin{array}{c}0.30^{a} \\
(0.039)\end{array}$ & $\begin{array}{l}0.28^{a} \\
(0.035)\end{array}$ & $\begin{array}{c}0.27^{a} \\
(0.035)\end{array}$ & $\begin{array}{c}0.27^{a} \\
(0.052)\end{array}$ & $\begin{array}{c}0.28^{a} \\
(0.052)\end{array}$ & $\begin{array}{l}1.17^{a} \\
(0.45)\end{array}$ & $\begin{array}{l}0.29^{a} \\
(0.11)\end{array}$ & $\begin{array}{l}0.18^{b} \\
(0.075)\end{array}$ \\
\hline$v_{b t}:$ Variety & $\begin{array}{l}0.18^{a} \\
(0.021)\end{array}$ & $\begin{array}{l}0.15^{a} \\
(0.017)\end{array}$ & $\begin{array}{l}0.14^{a} \\
(0.015)\end{array}$ & $\begin{array}{l}0.14^{a} \\
(0.015)\end{array}$ & $\begin{array}{l}0.16^{a} \\
(0.025)\end{array}$ & $\begin{array}{c}0.16^{a} \\
(0.025)\end{array}$ & $\begin{array}{l}0.59^{a} \\
(0.18)\end{array}$ & $\begin{array}{c}0.27^{a} \\
(0.054)\end{array}$ & $\begin{array}{l}0.083^{a} \\
(0.028)\end{array}$ \\
\hline $\begin{array}{l}p_{b t} v_{b t}: \text { Interaction } \\
(\text { Products } \times \text { Variety })\left(\times 10^{-2}\right)\end{array}$ & $\begin{array}{r}-0.85^{a} \\
(0.18)\end{array}$ & $\begin{array}{r}-0.73^{a} \\
(0.14)\end{array}$ & $\begin{array}{r}-0.67^{a} \\
(0.13)\end{array}$ & $\begin{array}{r}-0.65^{a} \\
(0.12)\end{array}$ & $\begin{array}{r}-0.75^{a} \\
(0.20)\end{array}$ & $\begin{array}{r}-0.78^{a} \\
(0.21)\end{array}$ & $\begin{array}{l}-11.0^{b} \\
(5.70)\end{array}$ & $\begin{array}{l}-1.90^{b} \\
(0.82)\end{array}$ & $\begin{array}{l}-0.41^{b} \\
(0.19)\end{array}$ \\
\hline $\begin{array}{l}g_{b, t-1}: \text { Growth } \\
(\operatorname{Lag} 1)\end{array}$ & & & $\begin{array}{l}-0.0058 \\
(0.026)\end{array}$ & $\begin{array}{l}-0.27^{a} \\
(0.095)\end{array}$ & $\begin{array}{r}-0.33^{a} \\
(0.11)\end{array}$ & $\begin{array}{r}-0.33^{a} \\
(0.11)\end{array}$ & $\begin{array}{l}-0.14 \\
(0.17)\end{array}$ & $\begin{array}{l}-0.33 \\
(0.21)\end{array}$ & $\begin{array}{l}-0.21 \\
(0.27)\end{array}$ \\
\hline $\begin{array}{l}x_{1 b t}: \text { Any PI Sales? } \\
(1 / 0 \text { Dummy, } 1 \text { if true })\end{array}$ & $\begin{array}{l}0.10^{a} \\
(0.028)\end{array}$ & $\begin{array}{l}0.11^{a} \\
(0.028)\end{array}$ & $\begin{array}{c}0.10^{a} \\
(0.025)\end{array}$ & $\begin{array}{l}0.100^{a} \\
(0.025)\end{array}$ & $\begin{array}{c}0.10^{a} \\
(0.035)\end{array}$ & $\begin{array}{c}0.10^{a} \\
(0.035)\end{array}$ & $\begin{array}{c}0.13 \\
(0.12)\end{array}$ & $\begin{array}{c}0.14^{a} \\
(0.050)\end{array}$ & $\begin{array}{c}0.041 \\
(0.043)\end{array}$ \\
\hline $\begin{array}{l}x_{2 b t}: \text { Any generic products? } \\
(1 / 0 \text { Dummy, } 1 \text { if true })\end{array}$ & $\begin{array}{c}-0.018 \\
(0.15)\end{array}$ & $\begin{array}{l}-0.17^{b} \\
(0.086)\end{array}$ & $\begin{array}{c}-0.14 \\
(0.092)\end{array}$ & $\begin{array}{c}-0.13 \\
(0.095)\end{array}$ & $\begin{array}{l}-0.051 \\
(0.12)\end{array}$ & $\begin{array}{c}-0.052 \\
(0.12)\end{array}$ & $\begin{array}{l}-0.45^{c} \\
(0.26)\end{array}$ & $\begin{array}{l}0.47^{c} \\
(0.26)\end{array}$ & $\begin{array}{l}-0.21^{b} \\
(0.087)\end{array}$ \\
\hline $\begin{array}{l}x_{1 c, t-1}: \text { Products in Class }\left(\times 10^{-2}\right) \\
\text { (Lag } 1 \text { of Products by Others) }\end{array}$ & $\begin{array}{c}0.23 \\
(0.37)\end{array}$ & $\begin{array}{l}0.012 \\
(0.39)\end{array}$ & $\begin{array}{c}-0.062 \\
(0.33)\end{array}$ & $\begin{array}{c}-0.0061 \\
(0.33)\end{array}$ & $\begin{array}{c}-0.013 \\
(0.49)\end{array}$ & $\begin{array}{c}0.0033 \\
(0.49)\end{array}$ & $\begin{array}{l}-0.60 \\
(1.3)\end{array}$ & $\begin{array}{c}1.40 \\
(0.91)\end{array}$ & $\begin{array}{l}-0.55 \\
(0.40)\end{array}$ \\
\hline $\begin{array}{l}x_{2 c, t-1}: \text { Varieties in Class }\left(\times 10^{-2}\right) \\
(\text { Lag } 1 \text { of Varieties by Others } 1)\end{array}$ & $\begin{array}{l}-0.57^{b} \\
(0.23)\end{array}$ & $\begin{array}{l}-0.22 \\
(0.16)\end{array}$ & $\begin{array}{l}-0.12 \\
(0.15)\end{array}$ & $\begin{array}{l}-0.12 \\
(0.15)\end{array}$ & $\begin{array}{r}-0.55^{b} \\
(0.27)\end{array}$ & $\begin{array}{l}-0.55^{b} \\
(0.27)\end{array}$ & $\begin{array}{l}-2.0^{b} \\
(0.91)\end{array}$ & $\begin{array}{c}0.32 \\
(0.50)\end{array}$ & $\begin{array}{l}-0.53^{b} \\
(0.26)\end{array}$ \\
\hline $\begin{array}{l}x_{3 c, t-1}: \text { HHI } \\
(\operatorname{Lag} 1)\end{array}$ & $\begin{array}{l}0.40^{b} \\
(0.18)\end{array}$ & $\begin{array}{l}0.33^{c} \\
(0.18)\end{array}$ & $\begin{array}{l}0.41^{b} \\
(0.17)\end{array}$ & $\begin{array}{l}0.41^{b} \\
(0.17)\end{array}$ & $\begin{array}{c}0.31 \\
(0.22)\end{array}$ & $\begin{array}{c}0.31 \\
(0.22)\end{array}$ & $\begin{array}{c}0.41^{c} \\
(0.23)\end{array}$ & $\begin{array}{c}0.24 \\
(0.46)\end{array}$ & $\begin{array}{l}-0.25 \\
(0.31)\end{array}$ \\
\hline $\begin{array}{l}x_{4 c, t-1}: \text { Firms in Class } \\
\left(\text { Lag 1) }\left(\times 10^{-2}\right)\right.\end{array}$ & $\begin{array}{l}-2.60^{b} \\
(1.00)\end{array}$ & $\begin{array}{l}-1.30 \\
(0.80)\end{array}$ & $\begin{array}{l}-0.58 \\
(0.76)\end{array}$ & $\begin{array}{l}-0.66 \\
(0.75)\end{array}$ & $\begin{array}{l}-1.10 \\
(1.20)\end{array}$ & $\begin{array}{l}-1.10 \\
(1.20)\end{array}$ & $\begin{array}{c}0.40 \\
(3.80)\end{array}$ & $\begin{array}{l}-3.0^{c} \\
(1.70)\end{array}$ & $\begin{array}{c}0.34 \\
(0.86)\end{array}$ \\
\hline $\begin{array}{l}\text { (Lags) } \\
g_{b, t-2}: \text { Growth } \\
(\text { Lag 2) }\end{array}$ & & & $\begin{array}{l}-0.13^{a} \\
(0.031)\end{array}$ & $\begin{array}{l}-0.33^{a} \\
(0.083)\end{array}$ & $\begin{array}{l}-0.41^{a} \\
(0.092)\end{array}$ & $\begin{array}{l}-0.41^{a} \\
(0.090)\end{array}$ & $\begin{array}{r}-0.32^{a} \\
(0.11)\end{array}$ & $\begin{array}{l}-0.34^{c} \\
(0.19)\end{array}$ & $\begin{array}{l}-0.26 \\
(0.19)\end{array}$ \\
\hline $\begin{array}{l}g_{b, t-3}: \text { Growth } \\
(\operatorname{Lag} 3)\end{array}$ & & & $\begin{array}{l}-0.14^{a} \\
(0.030)\end{array}$ & $\begin{array}{l}-0.27^{a} \\
(0.061)\end{array}$ & $\begin{array}{l}-0.34^{a} \\
(0.070)\end{array}$ & $\begin{array}{l}-0.34^{a} \\
(0.069)\end{array}$ & $\begin{array}{l}-0.32^{a} \\
(0.069)\end{array}$ & $\begin{array}{l}-0.26^{c} \\
(0.14)\end{array}$ & $\begin{array}{l}-0.19 \\
(0.14)\end{array}$ \\
\hline $\begin{array}{l}g_{b, t-4}: \text { Growth } \\
\text { (Lag 4) }\end{array}$ & & & $\begin{array}{l}-0.018 \\
(0.012)\end{array}$ & $\begin{array}{r}-0.072^{a} \\
(0.023)\end{array}$ & $\begin{array}{l}-0.11^{a} \\
(0.030)\end{array}$ & $\begin{array}{l}-0.11^{a} \\
(0.030)\end{array}$ & $\begin{array}{l}-0.12^{a} \\
(0.035)\end{array}$ & $\begin{array}{l}-0.083 \\
(0.055)\end{array}$ & $\begin{array}{r}-0.0075 \\
(0.060)\end{array}$ \\
\hline $\begin{array}{l}p_{b, t-1}: \text { Products } \\
(\text { Lag1) }\end{array}$ & & $\begin{array}{c}0.11^{a} \\
(0.019)\end{array}$ & $\begin{array}{c}0.10^{a} \\
(0.018)\end{array}$ & $\begin{array}{l}0.092^{a} \\
(0.019)\end{array}$ & $\begin{array}{l}0.074^{a} \\
(0.027)\end{array}$ & $\begin{array}{c}0.10^{a} \\
(0.027)\end{array}$ & $\begin{array}{c}0.41^{b} \\
(0.16)\end{array}$ & $\begin{array}{c}0.15^{c} \\
(0.077)\end{array}$ & $\begin{array}{l}0.043^{b} \\
(0.019)\end{array}$ \\
\hline$p_{b, t-2}:$ Products & & -0.0026 & $0.039^{b}$ & 0.017 & 0.059 & 0.041 & 0.19 & $0.086^{c}$ & 0.018 \\
\hline \multicolumn{10}{|c|}{ (Continued on next page) } \\
\hline $\begin{array}{l}\text { Observations } \\
\text { R-squared }\end{array}$ & $\begin{array}{c}50,942 \\
0.535\end{array}$ & $\begin{array}{c}44,893 \\
0.514\end{array}$ & $\begin{array}{c}42,994 \\
0.513\end{array}$ & $\begin{array}{c}42,994 \\
0.507\end{array}$ & $\begin{array}{c}23,054 \\
0.521\end{array}$ & $\begin{array}{c}23,054 \\
0.521\end{array}$ & $\begin{array}{l}5,581 \\
0.624\end{array}$ & $\begin{array}{l}8,334 \\
0.462\end{array}$ & $\begin{array}{l}9,139 \\
0.395\end{array}$ \\
\hline
\end{tabular}

${ }_{\dagger}^{\dagger}$ Standard errors are in parenthesis and clustered by business unit (firm-atc4 combination). Superscripts $a, b, c$ indicate significance at $1 \%, 5 \%$ and $10 \%$, respectively. All regressions include additional controls at the class- and firm-level, as well as indicator variables for year and quarter. Specification (1) does not include any lag, (2) is a distributed lag model and includes up to four lags of products, varieties and interactions. Specification (3) is an augmented distributed lag model, and additionally includes up to four lags of the dependent variable (i.e., growth). Specification (4) treats only the first lag of growth as endogenous, (5) treats the first lag of growth, as well as products, and varieties, and their interaction and all four lags of each of these as endogenous variables (total 16), and specification (6) treats the first lag of growth and only the contemporaneous values of products, varieties and interaction as endogenous variables (total of 4 endogenous variables). Specifications (6S), (6M), and (6L) are same as (6), but on sub-samples by initial size of business unit being (s)mall, (m)edium and (l)arge.

${ }^{\dagger \dagger}$ For brevity, we provide the sum of coefficients of the lagged variables. Individual coefficients for each of the lags is given in the appendix. The standard error on the sum of lagged coefficients is computed using the 'delta' method and accounts for clustering.

$\ddagger \ddagger$ Marginal effects are computed at the sample mean. The account for the interaction terms, the lagged values of the variable as well as the lagged values of growth. Standard errors are computed using the delta method. 
TABle A-1. FD Growth Models ${ }^{\dagger}$

\begin{tabular}{|c|c|c|c|c|c|c|c|c|c|}
\hline & \multicolumn{3}{|c|}{ OLS } & \multicolumn{3}{|c|}{ IV } & \multicolumn{3}{|c|}{ (6) By business unit size } \\
\hline & (1) & $(2)$ & $(3)$ & $(4)$ & $(5)$ & (6) & $(6 \mathrm{~S})$ & $(6 \mathrm{M})$ & $(6 \mathrm{~L})$ \\
\hline$(\operatorname{Lag} 2)$ & & $(0.027)$ & $(0.018)$ & $(0.019)$ & $(0.038)$ & $(0.026)$ & $(0.14)$ & $(0.051)$ & $(0.023)$ \\
\hline $\begin{array}{l}p_{b, t-3}: \text { Products } \\
\text { (Lag 3) }\end{array}$ & & $\begin{array}{c}0.021 \\
(0.015)\end{array}$ & $\begin{array}{c}0.021 \\
(0.015)\end{array}$ & $\begin{array}{r}-0.0048 \\
(0.019)\end{array}$ & $\begin{array}{r}-0.0037 \\
(0.026)\end{array}$ & $\begin{array}{r}-0.0035 \\
(0.018)\end{array}$ & $\begin{array}{c}0.023 \\
(0.072)\end{array}$ & $\begin{array}{l}-0.042 \\
(0.055)\end{array}$ & $\begin{array}{c}-0.00028 \\
(0.016)\end{array}$ \\
\hline $\begin{array}{l}p_{b, t-4}: \text { Products } \\
(\text { Lag } 4)\end{array}$ & & $\begin{array}{l}0.067^{b} \\
(0.027)\end{array}$ & $\begin{array}{l}0.030^{c} \\
(0.017)\end{array}$ & $\begin{array}{l}0.0073 \\
(0.018)\end{array}$ & $\begin{array}{c}0.025 \\
(0.024)\end{array}$ & $\begin{array}{c}0.012 \\
(0.019)\end{array}$ & $\begin{array}{c}0.16^{b} \\
(0.078)\end{array}$ & $\begin{array}{l}-0.019 \\
(0.049)\end{array}$ & $\begin{array}{l}0.0042 \\
(0.017)\end{array}$ \\
\hline $\begin{array}{l}v_{b, t-1}: \text { Variety } \\
(\operatorname{Lag} 1)\end{array}$ & & $\begin{array}{l}0.040^{a} \\
(0.008)\end{array}$ & $\begin{array}{l}0.043^{a} \\
(0.007)\end{array}$ & $\begin{array}{l}0.036^{a} \\
(0.007)\end{array}$ & $\begin{array}{l}0.040^{a} \\
(0.011)\end{array}$ & $\begin{array}{l}0.041^{a} \\
(0.010)\end{array}$ & $\begin{array}{c}0.20^{a} \\
(0.070)\end{array}$ & $\begin{array}{c}0.12^{a} \\
(0.038)\end{array}$ & $\begin{array}{c}0.019^{b} \\
(0.008)\end{array}$ \\
\hline $\begin{array}{l}v_{b, t-2}: \text { Variety } \\
(\operatorname{Lag} 2)\left(\times 10^{-2}\right)\end{array}$ & & $\begin{array}{l}-0.32 \\
(0.99)\end{array}$ & $\begin{array}{l}1.20^{c} \\
(0.68)\end{array}$ & $\begin{array}{c}-0.066 \\
(0.85)\end{array}$ & $\begin{array}{c}0.98 \\
(1.60)\end{array}$ & $\begin{array}{c}0.19 \\
(0.92)\end{array}$ & $\begin{array}{c}5.10 \\
(4.80)\end{array}$ & $\begin{array}{l}4.50 \\
(3.00)\end{array}$ & $\begin{array}{c}0.17 \\
(0.76)\end{array}$ \\
\hline $\begin{array}{l}v_{b, t-3}: \text { Variety } \\
(\operatorname{Lag} 3)\left(\times 10^{-2}\right)\end{array}$ & & $\begin{array}{l}1.00^{c} \\
(0.59)\end{array}$ & $\begin{array}{c}0.90 \\
(0.55)\end{array}$ & $\begin{array}{l}-0.48 \\
(0.65)\end{array}$ & $\begin{array}{c}-0.92 \\
(1.10)\end{array}$ & $\begin{array}{l}-0.93 \\
(0.78)\end{array}$ & $\begin{array}{c}-0.25 \\
(4.70)\end{array}$ & $\begin{array}{l}-1.40 \\
(2.50)\end{array}$ & $\begin{array}{l}-0.16 \\
(0.55)\end{array}$ \\
\hline $\begin{array}{l}v_{b, t-4}: \text { Variety } \\
(\operatorname{Lag} 4)\left(\times 10^{-2}\right)\end{array}$ & & $\begin{array}{l}2.20^{b} \\
(1.10)\end{array}$ & $\begin{array}{c}0.11 \\
(0.65)\end{array}$ & $\begin{array}{l}-1.00 \\
(0.72)\end{array}$ & $\begin{array}{c}-0.92 \\
(1.40)\end{array}$ & $\begin{array}{l}-1.60 \\
(0.99)\end{array}$ & $\begin{array}{l}-3.30 \\
(4.80)\end{array}$ & $\begin{array}{l}-0.82 \\
(2.10)\end{array}$ & $\begin{array}{l}0.047 \\
(0.50)\end{array}$ \\
\hline $\begin{array}{l}p_{b, t-1} v_{3, t-1}: \text { Interaction } \\
(\text { Products } \times \text { Variety, Lag } 1)\left(\times 10^{-2}\right)\end{array}$ & & $\begin{array}{l}-0.26^{a} \\
(0.052)\end{array}$ & $\begin{array}{l}-0.26^{a} \\
(0.051)\end{array}$ & $\begin{array}{l}-0.22^{a} \\
(0.048)\end{array}$ & $\begin{array}{l}-0.22^{b} \\
(0.087)\end{array}$ & $\begin{array}{l}-0.30^{a} \\
(0.084)\end{array}$ & $\begin{array}{c}-3.30^{c} \\
(2.0)\end{array}$ & $\begin{array}{l}-1.10 \\
(0.65)\end{array}$ & $\begin{array}{l}-0.14^{b} \\
(0.060)\end{array}$ \\
\hline $\begin{array}{l}p_{2, t-2} v_{3, t-2}: \text { Interaction } \\
(\text { Products } \times \text { Variety, Lag } 2)\left(\times 10^{-2}\right)\end{array}$ & & $\begin{array}{l}-0.044 \\
(0.061)\end{array}$ & $\begin{array}{l}-0.13^{a} \\
(0.042)\end{array}$ & $\begin{array}{l}-0.067 \\
(0.045)\end{array}$ & $\begin{array}{l}-0.20^{c} \\
(0.12)\end{array}$ & $\begin{array}{l}-0.15^{b} \\
(0.066)\end{array}$ & $\begin{array}{l}-1.30 \\
(1.30)\end{array}$ & $\begin{array}{l}-0.63^{b} \\
(0.32)\end{array}$ & $\begin{array}{l}-0.065 \\
(0.053)\end{array}$ \\
\hline $\begin{array}{l}p_{2, t-3} v_{3, t-3}: \text { Interaction } \\
(\text { Products } \times \text { Variety, Lag } 3)\left(\times 10^{-2}\right)\end{array}$ & & $\begin{array}{l}-0.053 \\
(0.035)\end{array}$ & $\begin{array}{l}-0.053 \\
(0.035)\end{array}$ & $\begin{array}{c}0.020 \\
(0.044)\end{array}$ & $\begin{array}{l}0.0054 \\
(0.077)\end{array}$ & $\begin{array}{c}-9.8 \mathrm{e}-04 \\
(0.049)\end{array}$ & $\begin{array}{l}-0.11 \\
(0.67)\end{array}$ & $\begin{array}{l}0.17 \\
(0.31)\end{array}$ & $\begin{array}{l}-0.010 \\
(0.034)\end{array}$ \\
\hline $\begin{array}{l}p_{2, t-4} v_{3, t-4}: \text { Interaction } \\
(\text { Products } \times \text { Variety, Lag } 4)\left(\times 10^{-2}\right)\end{array}$ & & $\begin{array}{l}-0.17^{a} \\
(0.062)\end{array}$ & $\begin{array}{l}-0.076^{b} \\
(0.037)\end{array}$ & $\begin{array}{l}-0.016 \\
(0.039)\end{array}$ & $\begin{array}{l}-0.087 \\
(0.082)\end{array}$ & $\begin{array}{l}-0.028 \\
(0.046)\end{array}$ & $\begin{array}{l}-0.83 \\
(0.84)\end{array}$ & $\begin{array}{c}3.2 \mathrm{e}-05 \\
(0.20)\end{array}$ & $\begin{array}{l}-0.014 \\
(0.029)\end{array}$ \\
\hline $\begin{array}{l}\tau_{1 t}: \text { Yr } 2004 \\
(1 / 0 \text { Dummy, } 1 \text { if true })\end{array}$ & $\begin{array}{l}-0.011 \\
(0.017)\end{array}$ & & & $\begin{array}{l}0.0044 \\
(0.023)\end{array}$ & $\begin{array}{l}-0.036 \\
(0.031)\end{array}$ & $\begin{array}{l}-0.034 \\
(0.031)\end{array}$ & & $\begin{array}{l}-0.068 \\
(0.045)\end{array}$ & $\begin{array}{l}-0.022 \\
(0.025)\end{array}$ \\
\hline $\begin{array}{l}\tau_{2 t}: \text { Yr } 2005 \\
(1 / 0 \text { Dummy, } 1 \text { if true })\end{array}$ & $\begin{array}{l}-0.015 \\
(0.017)\end{array}$ & $\begin{array}{r}-0.032^{b} \\
(0.016)\end{array}$ & $\begin{array}{l}-0.019 \\
(0.018)\end{array}$ & $\begin{array}{l}-0.012 \\
(0.018)\end{array}$ & $\begin{array}{l}-0.047^{b} \\
(0.021)\end{array}$ & $\begin{array}{l}-0.047^{b} \\
(0.021)\end{array}$ & $\begin{array}{l}-0.026 \\
(0.096)\end{array}$ & $\begin{array}{l}-0.046 \\
(0.035)\end{array}$ & $\begin{array}{r}-0.057^{b} \\
(0.027)\end{array}$ \\
\hline $\begin{array}{l}\tau_{3 t}: \text { Yr } 2006 \\
(1 / 0 \text { Dummy, } 1 \text { if true })\end{array}$ & $\begin{array}{c}-0.0083 \\
(0.018)\end{array}$ & $\begin{array}{l}-0.022 \\
(0.015)\end{array}$ & $\begin{array}{c}-0.0089 \\
(0.017)\end{array}$ & $\begin{array}{c}-0.0046 \\
(0.018)\end{array}$ & $\begin{array}{r}-0.046^{b} \\
(0.023)\end{array}$ & $\begin{array}{l}-0.045^{b} \\
(0.023)\end{array}$ & $\begin{array}{l}-0.035 \\
(0.089)\end{array}$ & $\begin{array}{l}-0.071^{c} \\
(0.038)\end{array}$ & $\begin{array}{l}-0.034 \\
(0.027)\end{array}$ \\
\hline $\begin{array}{l}\tau_{4 t}: \text { Yr } 2007 \\
(1 / 0 \text { Dummy, } 1 \text { if true })\end{array}$ & $\begin{array}{c}0.00049 \\
(0.017)\end{array}$ & $\begin{array}{l}-0.019 \\
(0.015)\end{array}$ & $\begin{array}{c}-0.0048 \\
(0.016)\end{array}$ & $\begin{array}{r}-0.0027 \\
(0.018)\end{array}$ & $\begin{array}{l}-0.052^{b} \\
(0.023)\end{array}$ & $\begin{array}{l}-0.051^{b} \\
(0.023)\end{array}$ & $\begin{array}{l}0.0055 \\
(0.088)\end{array}$ & $\begin{array}{l}-0.074^{c} \\
(0.040)\end{array}$ & $\begin{array}{l}-0.056^{b} \\
(0.025)\end{array}$ \\
\hline $\begin{array}{l}\tau_{5 t}: \text { Yr } 2008 \\
(1 / 0 \text { Dummy, } 1 \text { if true })\end{array}$ & $\begin{array}{c}0.0012 \\
(0.018)\end{array}$ & $\begin{array}{l}-0.018 \\
(0.015)\end{array}$ & $\begin{array}{r}-0.0089 \\
(0.017)\end{array}$ & $\begin{array}{r}-0.0031 \\
(0.018)\end{array}$ & $\begin{array}{l}-0.048^{b} \\
(0.023)\end{array}$ & $\begin{array}{l}-0.047^{b} \\
(0.023)\end{array}$ & $\begin{array}{c}-0.0042 \\
(0.092)\end{array}$ & $\begin{array}{l}-0.073^{b} \\
(0.036)\end{array}$ & $\begin{array}{l}-0.038 \\
(0.027)\end{array}$ \\
\hline $\begin{array}{l}\tau_{6 t}: \text { Yr } 2009 \\
(1 / 0 \text { Dummy, } 1 \text { if true) }\end{array}$ & $\begin{array}{l}-0.018 \\
(0.017)\end{array}$ & $\begin{array}{l}-0.031^{b} \\
(0.015)\end{array}$ & $\begin{array}{l}-0.014 \\
(0.017)\end{array}$ & $\begin{array}{c}-0.0093 \\
(0.018)\end{array}$ & $\begin{array}{l}-0.051^{b} \\
(0.022)\end{array}$ & $\begin{array}{l}-0.050^{b} \\
(0.022)\end{array}$ & $\begin{array}{c}0.014 \\
(0.090)\end{array}$ & $\begin{array}{r}-0.100^{a} \\
(0.039)\end{array}$ & $\begin{array}{l}-0.031 \\
(0.025)\end{array}$ \\
\hline
\end{tabular}

(Continued on next page)

\begin{tabular}{|c|c|c|c|c|c|c|c|c|}
\hline & & & & & & & & \\
\hline \multicolumn{9}{|c|}{$\begin{array}{l}\text { tandard errors are in parenthesis and clustered by business unit (f } \\
6,5 \% \text { and } 10 \% \text {, respectively. All regressions include additional contro } \\
\mathrm{d} \text { quarter. Specification (1) does not include any lag, }(2) \text { is a distrit } \\
\text { d interactions. Specification (3) is an augmented distributed lag } \mathrm{n} \\
\text { riable (i.e., growth). Specification (4) treats only the first lag of gr } \\
\text { oducts, and varieties, and their interaction and all four lags of each } \\
\text { eats the first lag of growth and only the contemporaneous values of } \\
4 \text { endogenous variables). Specifications }(6 \mathrm{~S}),(6 \mathrm{M}) \text {, and }(6 \mathrm{~L}) \text { are sar }\end{array}$} \\
\hline
\end{tabular}


TABLE A-1. FD Growth Models ${ }^{\dagger}$

\begin{tabular}{|c|c|c|c|c|c|c|c|c|c|}
\hline & \multicolumn{3}{|c|}{ OLS } & \multicolumn{3}{|c|}{ IV } & \multicolumn{3}{|c|}{ (6) By business unit size } \\
\hline & (1) & $(2)$ & (3) & (4) & $(5)$ & (6) & $(6 \mathrm{~S})$ & $(6 \mathrm{M})$ & $(6 \mathrm{~L})$ \\
\hline $\begin{array}{l}\tau_{7 t}: \text { Yr } 2010 \\
(1 / 0 \text { Dummy, } 1 \text { if true })\end{array}$ & $\begin{array}{l}-0.015 \\
(0.017)\end{array}$ & $\begin{array}{l}-0.026^{c} \\
(0.015)\end{array}$ & $\begin{array}{l}-0.011 \\
(0.017)\end{array}$ & $\begin{array}{r}-0.0040 \\
(0.018)\end{array}$ & $\begin{array}{l}-0.049^{b} \\
(0.023)\end{array}$ & $\begin{array}{l}-0.049^{b} \\
(0.023)\end{array}$ & $\begin{array}{l}-0.011 \\
(0.086)\end{array}$ & $\begin{array}{l}-0.084^{b} \\
(0.040)\end{array}$ & $\begin{array}{l}-0.034 \\
(0.025)\end{array}$ \\
\hline $\begin{array}{l}\tau_{8 t}: \text { Yr } 2011 \\
(1 / 0 \text { Dummy, } 1 \text { if true })\end{array}$ & $\begin{array}{l}-0.033^{c} \\
(0.017)\end{array}$ & $\begin{array}{r}-0.042^{a} \\
(0.014)\end{array}$ & $\begin{array}{l}-0.023 \\
(0.016)\end{array}$ & $\begin{array}{l}-0.016 \\
(0.018)\end{array}$ & $\begin{array}{l}-0.051^{b} \\
(0.023)\end{array}$ & $\begin{array}{l}-0.051^{b} \\
(0.023)\end{array}$ & $\begin{array}{c}-0.0034 \\
(0.088)\end{array}$ & $\begin{array}{l}-0.064^{c} \\
(0.037)\end{array}$ & $\begin{array}{l}-0.058^{b} \\
(0.025)\end{array}$ \\
\hline $\begin{array}{l}\tau_{9 t}: \text { Yr } 2012 \\
(1 / 0 \text { Dummy, } 1 \text { if true })\end{array}$ & $\begin{array}{l}-0.014 \\
(0.017)\end{array}$ & $\begin{array}{l}-0.021 \\
(0.014)\end{array}$ & $\begin{array}{c}-0.0085 \\
(0.017)\end{array}$ & $\begin{array}{l}0.0012 \\
(0.018)\end{array}$ & $\begin{array}{l}-0.040^{c} \\
(0.023)\end{array}$ & $\begin{array}{r}-0.039^{c} \\
(0.023)\end{array}$ & $\begin{array}{c}0.023 \\
(0.087)\end{array}$ & $\begin{array}{r}-0.083^{b} \\
(0.039)\end{array}$ & $\begin{array}{l}-0.031 \\
(0.030)\end{array}$ \\
\hline $\begin{array}{l}\tau_{10 t}: \text { Yr } 2013 \\
(1 / 0 \text { Dummy, } 1 \text { if true })\end{array}$ & $\begin{array}{l}-0.023 \\
(0.022)\end{array}$ & $\begin{array}{l}-0.024 \\
(0.022)\end{array}$ & $\begin{array}{c}-0.0084 \\
(0.023)\end{array}$ & & & & $\begin{array}{c}0.0088 \\
(0.10)\end{array}$ & & \\
\hline $\begin{array}{l}\tau_{11 t}: \text { Qtr } 2 \\
(1 / 0 \text { Dummy, } 1 \text { if true) }\end{array}$ & $\begin{array}{c}0.068^{a} \\
(0.0090)\end{array}$ & $\begin{array}{l}0.081^{a} \\
(0.0088)\end{array}$ & $\begin{array}{c}0.072^{a} \\
(0.0083)\end{array}$ & $\begin{array}{c}0.071^{a} \\
(0.0084)\end{array}$ & $\begin{array}{c}0.083^{a} \\
(0.012)\end{array}$ & $\begin{array}{l}0.082^{a} \\
(0.012)\end{array}$ & $\begin{array}{c}0.032 \\
(0.026)\end{array}$ & $\begin{array}{c}0.10^{a} \\
(0.022)\end{array}$ & $\begin{array}{l}0.092^{a} \\
(0.015)\end{array}$ \\
\hline $\begin{array}{l}\tau_{12 t}: \text { Qtr } 3 \\
\text { (1/0 Dummy, } 1 \text { if true) }\end{array}$ & $\begin{array}{l}0.062^{a} \\
(0.015)\end{array}$ & $\begin{array}{l}0.055^{a} \\
(0.011)\end{array}$ & $\begin{array}{l}0.041^{a} \\
(0.0081)\end{array}$ & $\begin{array}{l}0.042^{a} \\
(0.0083)\end{array}$ & $\begin{array}{l}0.043^{a} \\
(0.011)\end{array}$ & $\begin{array}{l}0.043^{a} \\
(0.011)\end{array}$ & $\begin{array}{l}0.044^{c} \\
(0.023)\end{array}$ & $\begin{array}{c}0.032 \\
(0.026)\end{array}$ & $\begin{array}{l}0.037^{a} \\
(0.012)\end{array}$ \\
\hline $\begin{array}{l}\tau_{13 t}: \text { Qtr } 4 \\
(1 / 0 \text { Dummy, } 1 \text { if true) }\end{array}$ & $\begin{array}{l}0.058^{a} \\
(0.012)\end{array}$ & $\begin{array}{l}0.056^{a} \\
(0.011)\end{array}$ & $\begin{array}{c}0.050^{a} \\
(0.0086)\end{array}$ & $\begin{array}{l}0.051^{a} \\
(0.0087)\end{array}$ & $\begin{array}{l}0.059^{a} \\
(0.012)\end{array}$ & $\begin{array}{l}0.058^{a} \\
(0.012)\end{array}$ & $\begin{array}{c}0.026 \\
(0.029)\end{array}$ & $\begin{array}{l}0.068^{a} \\
(0.025)\end{array}$ & $\begin{array}{l}0.048^{a} \\
(0.012)\end{array}$ \\
\hline$x_{0 t}$ : Constant & $\begin{array}{r}-0.069^{a} \\
(0.018)\end{array}$ & $\begin{array}{r}-0.065^{a} \\
(0.013)\end{array}$ & $\begin{array}{r}-0.077^{a} \\
(0.016)\end{array}$ & $\begin{array}{r}-0.082^{a} \\
(0.015)\end{array}$ & $\begin{array}{l}-0.042^{b} \\
(0.018)\end{array}$ & $\begin{array}{l}-0.042^{b} \\
(0.018)\end{array}$ & $\begin{array}{l}-0.064 \\
(0.086)\end{array}$ & $\begin{array}{l}-0.027 \\
(0.029)\end{array}$ & $\begin{array}{l}-0.030 \\
(0.024)\end{array}$ \\
\hline $\begin{array}{l}\text { Observations } \\
\text { R-squared }\end{array}$ & $\begin{array}{l}50,942 \\
0.535\end{array}$ & $\begin{array}{l}44,893 \\
0.514\end{array}$ & $\begin{array}{l}42,994 \\
0.513\end{array}$ & $\begin{array}{l}42,994 \\
0.507\end{array}$ & $\begin{array}{c}23,054 \\
0.521\end{array}$ & $\begin{array}{c}23,054 \\
0.521\end{array}$ & $\begin{array}{l}5,581 \\
0.624\end{array}$ & $\begin{array}{l}8,334 \\
0.462\end{array}$ & $\begin{array}{l}9,139 \\
0.395\end{array}$ \\
\hline
\end{tabular}

$\dagger$ Standard errors are in parenthesis and clustered by business unit (firm-atc4 combination). Superscripts $a, b, c$ indicate significance at $1 \%, 5 \%$ and 10\%, respectively. All regressions include additional controls at the class- and firm-level, as well as indicator variables for year and quarter. Specification (1) does not include any lag, (2) is a distributed lag model and includes up to four lags of products, varieties and interactions. Specification (3) is an augmented distributed lag model, and additionally includes up to four lags of the dependent variable (i.e., growth). Specification (4) treats only the first lag of growth as endogenous, (5) treats the first lag of growth, as well as products, and varieties, and their interaction and all four lags of each of these as endogenous variables (total 16), and specification (6) treats the first lag of growth and only the contemporaneous values of products, varieties and interaction as endogenous variables (total of 4 endogenous variables). Specifications (6S), (6M), and (6L) are same as (6), but on sub-samples by initial size of business unit being (s)mall, (m)edium and (l)arge.

$\dagger^{\dagger}$ For brevity, we provide the sum of coefficients of the lagged variables. Individual coefficients for each of the lags is given in the appendix. The standard error on the sum of lagged coefficients is computed using the 'delta' method and accounts for clustering.

$\ddagger \ddagger$ Marginal effects are computed at the sample mean. The account for the interaction terms, the lagged values of the variable as well as the lagged values of growth. Standard errors are computed using the delta method. 
TABLE A-2. First stage and other tests for instruments

\begin{tabular}{|c|c|c|c|c|c|c|}
\hline & $(4)$ & $(5)$ & (6) & $(6 a)$ & $(6 \mathrm{~b})$ & $(6 c)$ \\
\hline \multicolumn{7}{|c|}{ Weak instruments tests } \\
\hline Endogenous Variable(s) & \multicolumn{6}{|c|}{ First-stage F-statistics } \\
\hline $\begin{array}{l}\left.g_{b, t-1}: \text { Growth (Lag } 1\right) \\
p_{b, t}: \text { Products } \\
v_{b, t}: \text { Variety } \\
p_{b t} * v_{b t}: \text { Interaction } \\
p_{b, t-1}: \text { Products (Lag 1) } \\
p_{b, t-2}: \text { Products (Lag 2) } \\
p_{b, t-3}: \text { Products (Lag 3) } \\
p_{b, t-4}: \text { Products (Lag 4) } \\
v_{b, t-1}: \text { Variety (Lag1) } \\
v_{b, t-2}: \text { Variety (Lag2) } \\
v_{b, t-3}: \text { Variety (Lag3) } \\
v_{b, t-4}: \text { Variety (Lag4) } \\
p_{b, t-1} * v_{b, t-1} \text { : Interaction (Lag 1) } \\
p_{b, t-2} * v_{b, t-2} \text { : Interaction (Lag 2) } \\
p_{b, t-3} * v_{b, t-3} \text { : Interaction (Lag 3) } \\
p_{b, t-4} * v_{b, t-4} \text { : Interaction (Lag 4) }\end{array}$ & 58.6 & $\begin{array}{l}17.58 \\
45.85 \\
63.6 \\
25.31 \\
80.16 \\
82.19 \\
88.94 \\
83.69 \\
62.93 \\
63.91 \\
67.02 \\
75.07 \\
43.72 \\
36.33 \\
32.5 \\
35.74\end{array}$ & $\begin{array}{c}38.27 \\
90.34 \\
202.76 \\
79.11\end{array}$ & $\begin{array}{l}20.39 \\
17.21 \\
57.75 \\
10.57\end{array}$ & $\begin{array}{l}15.92 \\
68.41 \\
109.1 \\
17.03\end{array}$ & $\begin{array}{c}22.6 \\
168.35 \\
121.82 \\
76.07\end{array}$ \\
\hline \multicolumn{7}{|c|}{ Under Identification Test (Ho: Model is under-identified) } \\
\hline $\begin{array}{l}\text { Chi-Square Value } \\
\text { DF } \\
\text { P-value }\end{array}$ & $\begin{array}{c}167.54 \\
1 \\
0\end{array}$ & $\begin{array}{c}140.06 \\
6 \\
0\end{array}$ & $\begin{array}{c}135.931 \\
2 \\
0\end{array}$ & $\begin{array}{c}10.891 \\
2 \\
0.0043\end{array}$ & $\begin{array}{c}12.143 \\
2 \\
0.0023\end{array}$ & $\begin{array}{l}32.434 \\
2 \\
0\end{array}$ \\
\hline \multicolumn{7}{|c|}{ Over Identification Test (Ho: Model is over identified) } \\
\hline $\begin{array}{l}\text { Chi-Square Value } \\
\text { DF } \\
\text { P-value }\end{array}$ & . & $\begin{array}{c}4.791 \\
5 \\
0.4419\end{array}$ & $\begin{array}{c}0.569 \\
1 \\
0.4507\end{array}$ & $\begin{array}{c}0.05 \\
1 \\
0.823\end{array}$ & $\begin{array}{c}0.061 \\
1 \\
0.8056\end{array}$ & $\begin{array}{c}2.438 \\
1 \\
0.1184\end{array}$ \\
\hline
\end{tabular}

